\title{
Enantioseparation and Enantioselective Analysis of Chiral Herbicides
}

\author{
Lixia Jin ${ }^{1}$, Weiliang Gaoㄹ, Ling $\mathrm{Li}^{1}$, Jing Ye², \\ Chunmian $\operatorname{Lin}^{1}$ and Weiping Liu ${ }^{1,2}$ \\ ${ }^{1}$ Research Center of Environmental Science, \\ College of Biological and Environmental Engineering, \\ Zhejiang University of Technology, Hangzhou 310032 \\ ${ }^{2}$ Ministry of Education Key Laboratory of \\ Environmental Remediation and Ecosystem Health, \\ College of Environmental and Resource Sciences, \\ Zhejiang University, Hangzhou 310029
}

China

\section{Introduction}

Many commercial agrochemicals in current use contain chiral structures and thus consist of enantiomers. Here chiral herbicide is one of the most important agrochemicals which are widely used. Enantiomers of a chiral compound have identical physical-chemical properties and appear as a single compound in standard analysis. However, the biological effects of enantiomers such as toxicity, mutagenicity, carcinogencity, and endocrine disruption activity, are generally different, due to the inherent enantioselectivity of biological interactions.

According to the chemical structure, the familiar chiral herbicides have been classified with amide herbicides, phenoxy herbicides, imidazolinone herbicides, organophosphorus herbicides and so on. The analysis and preparation of pure enantiomer herbicides have been summarized with HPLC, GC, CE and SFC methods. Finally, information concerning the stereoselective toxicity and degradation of chiral herbicides in environmental behavior has been offered. 


\section{Classification of chiral herbicides}

\subsection{Amide herbicides}<smiles>CC(=O)C(=O)N(C(=O)c1ccccc1)c1ccc(Cl)c(Cl)c1</smiles>

benzoylprop<smiles>CC(=O)N(C(=O)c1ccccc1)c1ccc(F)c(Cl)c1</smiles>

flamprop

arylalanine herbicides<smiles>COCc1cccc(C(O)c2nc(OC)cc(OC)n2)c1NS(=O)(=O)C(F)F</smiles>

pyrimisulfan<smiles>CCc1cccc(C)c1N(C(=O)CCl)C(C)COC</smiles>

metolachlor<smiles>CCOCN(C(=O)CCl)c1c(C)cccc1CC</smiles>

acetochlor chloroacetanilide herbicides

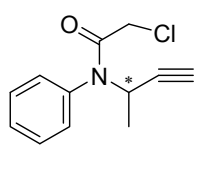

prynachlor<smiles>O=C1[C@H]2CC(F)=CN2C(=O)N1c1cc(NS(=O)(=O)CCl)c(Cl)cc1F</smiles>

sulfonanilide herbicides<smiles>CC(=O)C(=O)Nc1ccccc1Oc1ccc(Cl)c(C)c1Cl</smiles>

clomeprop<smiles>C[C@@H]1CC[C@@H](C)N1C(=O)Nc1ccccc1</smiles>

cisanilide<smiles>CCC[C@H](C)C(=O)Nc1ccc(Cl)c(Cl)c1</smiles>

(RS)-3',4'-dichloro-2-methylvaleranilide<smiles>CCCC(=O)C(C)Nc1ccc(C)c(Cl)c1</smiles>

pentanochlor<smiles>CCN(CC)C(=O)[C@H](C)Oc1cccc2ccccc12</smiles>

napropamide<smiles>CC(=O)C(=O)Nc1ccccc1</smiles>

naproanilide anilide herbicides<smiles>CC(C(=O)Oc1ccc(Oc2nc3ccc(Cl)cc3o2)cc1)N(C)c1ccccc1F</smiles>

metamifop<smiles>CCCCOC(=O)C(=O)NCc1ccccc1</smiles><smiles>COC[C@H](C)N(C(=O)CCl)c1c(C)csc1C</smiles> 


\subsection{Phenoxy herbicides}<smiles>Cc1c(Cl)ccc(OC(C)C(=O)Nc2ccccc2)c1Cl</smiles><smiles>CCCCCCC(C)OC(=O)COc1nc(F)c(Cl)c(N)c1Cl</smiles><smiles>CC(=CC(=O)O)Oc1ccc(Oc2ccc(C(F)(F)F)cc2)cc1</smiles>
difenopenten<smiles>CCCCC(CC)OC(=O)COc1ccc(Cl)cc1Cl</smiles>

2,4-D-ethylhexyl<smiles>CCNC(=O)C(C)Oc1cc(Oc2ccc(Cl)cc2Cl)ccc1[N+](=O)[O-]</smiles><smiles>CC(C)=NOC(=O)C(C)Oc1ccc(Oc2ccc(C(F)(F)F)cc2)cc1</smiles>

trifopsime<smiles>CC(Oc1cccc(Cl)c1)C(=O)O</smiles>

cloprop<smiles>CC(Oc1ccc(Cl)c(Cl)c1)C(=O)O</smiles>

3,4-DP<smiles>CC(Oc1ccc(Cl)cc1)C(=O)O</smiles>

4-CPP<smiles>CC(Oc1cc(Cl)c(Cl)cc1Cl)C(=O)O</smiles>

fenoprop

phenoxypropionic herbicides<smiles>CC(Oc1ccc(Cl)cc1Cl)C(=O)O</smiles>

dichlorprop<smiles>Cc1cc(Cl)ccc1OC(C)C(=O)O</smiles>

mecoprop 
<smiles>C[C@H](Oc1ccc(Oc2ncc(Cl)cc2Cl)cc1)C(=O)O</smiles>

chlorazifop<smiles>Clc1ccc(Cl)cc1</smiles><smiles>CC(Oc1ccc(F)cc1)C(=O)O</smiles>
clofop<smiles>C[C@H](Oc1ccc(Oc2ccc(C(F)(F)F)cn2)cc1)C(=O)O</smiles>
fluazifop<smiles>C[C@H](Oc1ccc(Oc2nc3ccc(Cl)cc3o2)cc1)C(=O)O</smiles>
fenoxaprop $\mathrm{Cl}$<smiles>CC(Oc1ccc(Oc2nc3ccc(Cl)cc3o2)cc1)C(=O)N(C)c1ccccc1F</smiles>
metamifop<smiles>C[C@@H](Oc1ccc(Oc2ncc(Cl)cc2F)cc1)C(=O)O</smiles>
clodinafop<smiles>CC(Oc1ccc(Oc2ccc(Cl)cc2Cl)cc1)C(=O)O</smiles>
diclofop<smiles>CC(Oc1ccc(Oc2ccc(C(F)(F)F)cc2)cc1)C(=O)O</smiles>

trifop<smiles>C[C@H](Oc1ccc(Oc2ccc(C#N)cc2F)cc1)C(=O)O</smiles>

cyhalofop<smiles>C[C](Oc1ccc(Oc2ncc(C(F)(F)F)cc2Cl)cc1)C(=O)O</smiles>
haloxyfop<smiles>CC(Oc1ccc(Oc2ncc(Cl)cc2Cl)cc1)C(=O)N1CCCO1</smiles>
isoxapyrifop<smiles>CC(Oc1ccc(Oc2nc3ccc(Cl)cc3s2)cc1)C(=O)O</smiles>
fenthiaprop<smiles>CC(Oc1ccc(Oc2cnc3cc(Cl)ccc3n2)cc1)C(=O)O</smiles><smiles>CC(C)=NOCCOC(=O)C(C)Oc1ccc(Oc2cnc3cc(Cl)ccc3n2)cc1</smiles>

propaquizafop

aryloxyphenoxypropionic herbicides

\subsection{Imidazolinone herbicides}<smiles>Cc1ccc(C(=O)O)c(C2=N[C@](C)(C(C)C)C(=O)N2)c1</smiles><smiles>Cc1ccc(C2=NC(C)(C(C)C)C(=O)N2)c(C(=O)O)c1</smiles>
imazamethabenz

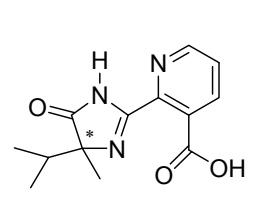

imazapyr<smiles>COCc1cnc(C2=NC(C)(C(C)C)C(=O)N2)c(C(=O)O)c1</smiles>

imazamox

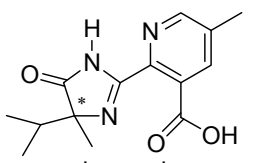

imazapic<smiles>CC(C)C1(C)N=C(c2nc3ccccc3cc2C(=O)O)NC1=O</smiles>

imazaquin<smiles>CCc1cnc(C2=NC(C)(C(C)C)C(=O)N2)c(C(=O)O)c1</smiles>

imazethapyr 


\subsection{Organophosphorus herbicides}<smiles>COP(=S)(NC(C)C)Oc1ccc(C)cc1[N+](=O)[O-]</smiles>

amiprofos-methyl<smiles>COP(=S)(NC(C)C)Oc1ccc(Cl)cc1Cl</smiles>

DMPA

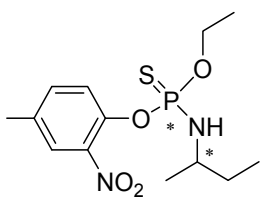

amiprofos

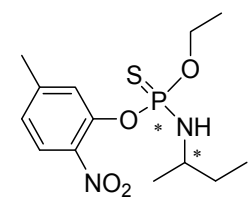

butamifos<smiles>CCOP(=O)(O)C(N)=O</smiles>

fosamine glufosinate<smiles>CCCOP(=S)(OCCC)SCC(=O)N1CCCCC1C</smiles>
piperophos<smiles>CC(NC(=O)C(C)NC(=O)C(N)CCP(C)(C)=O)C(=O)O</smiles>

bilanafos

\subsection{Diphenyl ether herbicides}<smiles>CC(OC(=O)c1cc(Oc2ccc(C(F)(F)F)cc2Cl)ccc1Cl)C(=O)O</smiles>
ethoxyfen<smiles>CCOC(=O)C(C)OC(=O)c1cc(Oc2ccc(C(F)(F)F)cc2Cl)ccc1[N+](=O)[O-]</smiles>

lactofen<smiles>O=[N+]([O-])c1ccc(Oc2ccc(C(F)(F)F)cc2Cl)cc1OC1CCOC1</smiles>

furyloxyfen

\subsection{Other herbicides}<smiles>CC1=CCCCCCCC1=O</smiles>

fluroxypyr butoxypropyl ester<smiles>CCCCCOCC(=O)OCc1nc(F)c(Cl)c(N)c1Cl</smiles>

fluroxypyr-butoxypropyl<smiles>CCO[C@H]1Oc2ccc(OS(C)(=O)=O)cc2C1(C)C</smiles>

ethofumesate<smiles>Cc1nn(-c2cc(C[C](Cl)C(=O)O)c(Cl)cc2F)c(=O)n1C(F)F</smiles>

carfentrazone

\section{Chromatographic methods for chiral herbicides}

\subsection{Separation of chiral herbicides by HPLC}

HPLC combined with kinds of CSPs is one of the most common and easily obtained approaches for enantiomer analysis and preparation. Today, CSPs have been developed at least seven classes, including Pirkle-type CSPs, polysaccharides CSPs, cyclodextrins CSPs, macrocyclic glycopeptide antibiotics CSPs, proteins CSPs, crown ethers CSPs and ligand exchange CSPs, etc. Profiting from the development of CSPs, chiral HPLC methods have held the balance both for determining optical purity of enantiomers and for preparing enantiopure standards.

A group of herbicides, diclofop-methyl, quizalofop-ethyl, lactofen, fluroxypyr-meptyl, acetochlor, ethofumesate, clethodim, napropamide, fenoxaprop-ethyl and carfentrazoneethyl, were partial or near-baseline separated on self-prepared amylose tris-(S)-1phenylethylcarbamate CSP by HPLC with $\eta$-hexane/isopropanol as mobile phase (Wang et al., 2006). 
Chiral pyrazole phenyl ethers (PPE) are highly active herbicides which were resolved by direct HPLC on commercially available CSPs derived from N-3,5-dinitrobenzoyl derivatives of a-amino acids or amines (Whelk-O 1). Chromatographic resolution obtained was suitable for determination of enantiomeric purities and, in some cases, for preparative resolution of the enantiomers with ee>99\% (Hamper et al., 1994). (+)- and (-)-enantiomers of thiobencarb sulfoxide were collected with purities more than $99.0 \%$ ee and $99.8 \%$ ee on a Chiralcel OB column at $25{ }^{\circ} \mathrm{C}, 1 \mathrm{~mL} / \mathrm{min} 95 / 2.5 / 2.5$ hexane/EtOH/MeOH as a mobile phase (Kodama $e t$ al., 2002).

\subsubsection{Enantioseparation of amide herbicides by HPLC}

Amide herbicides are a group of important chiral herbicides, and metolachlor, which contains two chiral elements (an asymmetrically substituted carbon and a chiral axis), consists of four stereoisomers stable at ambient temperature with aSS-, aRS-, aSR-, and aRRconfigurations. Two of the four metolachlor isomers were isolated from rac-metolachlor in enantio- (ee $>98 \%$ ) and diastereomerically pure forms by a combination of achiral Hypercarb $\mathrm{PH}$ and chiral chiralcel OD-H HPLC with 98/2 n-hexane/IPA. The enantiomer elution sequence is aS prior to aR (retention times, aSS $<\mathrm{aRS}$ and $\mathrm{aSR}<\mathrm{aRR}$ ) and $1^{\prime} \mathrm{S}$ prior to $1^{\prime} \mathrm{R}$ (retention times, aSS $<$ aSR and aRS<aRR) (Muller et al., 2001). Baseline separation of four metolachlor isomers by HPLC was achieved on Chiralcel OD-H using 91/9 Hex/diethyl ether as the mobile phase by Polcaro et al. (Polcaro et al., 2004). Enantiomers and diastereomers of some acetamide pesticides, alachlor, acetochlor, metolachlor, and dimethenamid, were separated using achiral and chiral high-resolution GC/MS (HRGC/MS) and chiral HPLC. Chiral HPLC using modified cellulose and phenylglycine columns also showed some isomer resolution. A novel thermal equilibration procedure allowed distinction among axial-chiral and C-chiral enantiomers (Buser et al., 1995). Additionally, acetochlor enantiomers were partial identified with a cellulose derivative fixed phase CDMPC by HPLC with n-hexane or petroleum ether with different percents alcohol (Peng et al., 2005). And dimethenamid-P was completely resolved on a normal phase Chiralpak AD-H column (Saito et al., 2008).

Another typical amide herbicide, napropamide, was separated both by normal phase HPLC and by reverse phase HPLC by Liu et al. (Chen et al., 2006, Zhou et al., 2006). In the former research, a method for the chiral separation and micro-determination of napropamide in water was established on a Chiralcel OJ-H column. The linearity of calibration curve for racemic mixture was $10-100 \mathrm{ng} / \mathrm{mL}$ and the correlation coefficient was 0.99 (Chen et al., 2006). In the latter, the enantiomers were resolved using Chiralcel AD-RH and Chiralcel OD$\mathrm{RH}$ with $\mathrm{MeCN} / \mathrm{H}_{2} \mathrm{O}$ as mobile phase. The stereoselectivity of Chiralcel AD-RH was better than Chiralcel OD-RH for napropamide (Zhou et al., 2006). In a report by Zhou et al. (Tian et al., 2010), napropamide was partially separated $\left(R_{s} 1.05\right)$ under $40 / 60 \mathrm{MeCN} /$ water reverse phase HPLC on amylose tris(3,5-dimethylphenylcarbamate) CSP (ADMPC).

Flamprop was resolved on $150 \times 4.6 \mathrm{~mm}$ I.D. terguride-based CSP (selectivity factor a 1.09) by using $45 \% 0.02 \mathrm{M}$ potassium acetate buffer ( $\mathrm{pH} 3.5$ ) and $55 \% \mathrm{MeCN}$ as the elution solvent by HPLC (Padiglioni et al., 1996).

\subsubsection{Enantioseparation of phenoxy herbicides by HPLC}

Phenoxy herbicides are a large group of chiral herbicides with widespread application in agriculture. The most representative herbicides are diclofop, mecoprop (MCPP), 
dichlorprop (DCPP) and their derivatives as classified with phenoxypropionic acids herbicides, which are widely applied to control broad-leaf weeds. In Padiglioni's study (Padiglioni et al., 1996), MCPP, DCPP, diclofop, fenoxaprop, fenoprop, fluazifop, haloxyfop, quizalofop-ethyl ester and quizalofop were well resolved on $150 \times 4.6 \mathrm{~mm}$ I.D. terguridebased CSP by using $0.02 \mathrm{M}$ potassium acetate buffer ( $\mathrm{pH}$ 3.5)-MeCN as the mobile phase by HPLC. Furthermore, a semipreparative-scale separation of fenoprop enantiomers was carried out on a $250 \times 7.8 \mathrm{~mm}$ I.D. column, yielding approximately $1.0 \mathrm{mg}$ of each enantiomer in a single chromatographic run, with a recovery of $88 \%$ and optical purity greater than $99 \%$.

Several phenoxypropionic acid herbicides were separated on two CD-derivatived CSPs, Nucleodex a-PM and Nucleodex $\beta$-PM. Phenoxypropionic acids can be divided into three different groups. The first one has one or two small substituents such as methyl, chlorine or hydroxyl at the aromatic ring (e.g. MCPP, DCPP). The separation of MCPP and DCPP was possibly conducted using NUCLEODEX a-PM CSP, whereas the methyl ester of these compounds was resolved by both Nucleodex a-PM and Nucleodex $\beta$-PM. A further substitution (e.g. fenoprop R1, R2. R3=C1, R4=H) leads to the second group and results in the failure of the permethylated a-CD to achieve separation, but fenoprop can be sufficiently resolved by Nucleodex $\beta$-PM. The third group contains compounds like fenoxaprop or diclotop with large substituents at the aromatic ring. In this case only the methyl or ethyl esters can be separated by permethylated $\beta$-CD. No resolution can be obtained with Nucleodex a-PM (Riering et al., 1996). Resolution of MCPP and DCPP and 2,4-D were proved to be obtained on Nucleodex-a-PM-CD CSP with $70 \% \mathrm{MeOH}$ and $30 \% 50 \mathrm{mM}$ $\mathrm{NaH}_{2} \mathrm{PO}_{4}$ as elutent by Kohler et al. (Zipper et al., 1999) and Bjerg et al. (Rugge et al., 2002).

$\mathrm{MCPP}$ and DCPP, and bromacil with a pyrimidinedione ring were better resolved on the native teicoplanin CSPs than the aglycone teicoplanin CSPs with 100\% $\mathrm{MeOH}$ containing $0.1 \%$ TEA and $0.1 \%$ acetic acid (v/v) and $20 / 80 \mathrm{MeOH} /$ water buffered at $\mathrm{pH} 4.1$ by $1 \%$ TEAA for bromacil by HPLC (Berthod et al., 2000a). Furthermore, MCPPM and DCPPM were better resolved on the native teicoplanin CSPs with $20 \% \mathrm{MeOH} / 80 \%$ aqueous buffer ( $\mathrm{pH} 4.1$ by TEAA, 1\%). However, the resolution for bromacil with a pyrimidinedione ring was higher on teicoplanin structurally related A-40926 CSP than on teicoplanin CSP $\left(\mathrm{R}_{\mathrm{s}} 2.8\right.$ vs. $\left.R_{s} 2.5\right)$ (Berthod et al., 2000b). Rac-diclofop methyl and rac-diclofop acid were baseline separated on a chiralcel OJ-H column using chiral HPLC coupled with fluorescence detection with a mobile phase of Hex/IPA/HAc (90:10:0.2, v/v) at a flow rate of 0.5 $\mathrm{mL} / \mathrm{min}$ under $20^{\circ} \mathrm{C}$ (Lin et al., 2006) while in a report by Zhou et al. (Gu et al., 2010), they were completely resolved on CDMPC CSP with $\operatorname{Hex} / \operatorname{IPA}(98: 2)$ containing $0.1 \%$ TFA as mobile phase by HPLC-DAD.

A group of 2-aryloxypropionic acids (TR-1 to 13) and their esters (TR-19 to 20) were used to evaluated four new brush-type CSPs (CSP I-IV) comprising N-3,5,6-trichloro-2,4dicyanophenyl-L-a-amino acids by HPLC. The best separation of these herbicides was obtained with CSP I, and the -(-)-S enantiomer were regularly eluted first. The mechanism of chiral recognition implies a synergistic interaction of carboxylic acid analyte with the chiral selector and achiral free $\gamma$-aminopropyl units on silica. (Vinkovic et al., 2001) In a study by Badjah-Hadj-Ahmed (Tazerouti et al., 2002), eleven 2-aryloxypropionic acids and esters herbicides were partially separated on the prepared phenylated $\beta$-CD CSP when using heptane and either IPA or chloroform as organic mobile phase modifier. 
Enantioseparation of 2,4-DP and MCPP was obtained completely using enantioselective HPLC on a chirobiotic $\mathrm{T}$ column with $5: 95 \mathrm{MeOH}$ and $1 \%$ TEAA as mobile phase (Schneiderheinze et al., 1999).

Fenoxaprop-ethyl could obtain baseline separation on ADMPC CSP by reversed phase HPLC with $\mathrm{MeOH} /$ water or $\mathrm{MeCN} /$ water at a flow rate of $0.5 \mathrm{~mL} / \mathrm{min}$, while the enantiomers of quizalofop-ethyl, fluroxypyr-meptyl and 2,4-D-ethylhexyl got partial separation (Tian et al., 2010).

A group of chlorophenoxypropionic acid herbicides 2,2-CPPA, 2,3-CPPA and 2,4-CPPA were separated in capillary LC, while with $0.1 \mathrm{mM}$ teicoplanin in the mobile phase was sufficient for the baseline enantioresolution of 2,2-CPPA and 2,4-CPPA (Kafkova et al., 2005). Eight commercially available herbicides, dimethenamid-P, dichlorprop-P, fluazifop-P butyl, mecoprop-P, quizalofop-P ethyl, were completely resolved by HPLC combined with a photodiode-array (PDA) detector and a circular dichroism (CD) detector on a normal phase Chiralpak AD-H column (Saito et al., 2008). Optical purity measurement was developed. The enantiomeric excess (ee) of some herbicides investigated was approximately over $95 \%$, while of quizalofop-P ethyl and fluazifop-P butyl was in the range $34.1-94.5 \%$.

\subsubsection{Enantioseparation of imidazolinone herbicides by HPLC}

Imidazolinones are a class of chiral herbicides that are widely used. They inhibit branchedchain amino acid biosynthesis in plants by targeting acetolactate synthase (ALS). Five imidazolinone herbicides imazapyr, imazapic, imazethapyr, imazamox and imazaquin and their methyl derivatives were separated using reversed phase HPLC on Chiralcel OD-R and normal phase HPLC on Chiralcel OJ (Lao et al., 2006a). Enantiomers of imazethapyr, imazaquin, and imazamox were separated on a Chiralcel OD-R column using $50 \mathrm{mM}$ phosphate buffer-MeCN as mobile phase. Enantiomers of imazethapyr, imazaquin, and imazamox were separated on a Chiralcel OD-R column using $50 \mathrm{mM}$ phosphate buffer$\mathrm{MeCN}$ as mobile phase. Enantiomers of imazapyr, imazapic, imazethapyr, imazamox, imazaquin and their five methyl derivatives were resolved on a Chiralcel OJ column using Hex $(0.1 \%$ TFAA)-alcohol as mobile phase. The described normal phase method was successfully applied for chiral analysis of two imidazolinone herbicides (imazapyr and imazaquin) in spiked soil samples. In a further report (Lao et al., 2006b), temperature affects on enantioseparation of these five imidazolinone herbicides and conformation of CSP were conducted on Chiralcel OJ. The van't Hoff plots of retention factor $\left(\mathrm{k}^{\prime}\right)$, distribution constant $(\mathrm{K})$ and separation factor $(\alpha)$ for imazapyr, imazapic, imazethapyr, and imazamox were linear within $15-50{ }^{\circ} \mathrm{C}$. Nonlinear van't Hoff plots of a were observed for imazaquin with mobile phase of Hex (0.1\% TFA)-IPA at $70 / 30$ or $60 / 40$ (v/v). Chiralcel OJ column may yield satisfactory results at $15-50{ }^{\circ} \mathrm{C}$ but not at $\leq 15^{\circ} \mathrm{C}$.

Recently, Lin et al. (Lin et al., 2007) also investigated the enantiomeric separation of imazethapyr, imazapyr, and imazaquin on Chiralpak AS, Chiralpak AD, Chiralcel OD, and Chiralcel OJ columns. Chiralcel OJ column showed the best chiral resolving capacity among the test columns. The optimal chromatographic conditions for complete separation of imidazolinone enantiomers were a mobile phase of Hex/EtOH/HAc (77/23/0.1, v/v/v), flow rate of $0.8 \mathrm{~mL} / \mathrm{min}$, and a column temperature in the range of $10-30^{\circ} \mathrm{C}$. It was showed that small amounts of enantiopure imidazolinones may be prepared by using the analytical chiral HPLC approach. 
Enantiomers of imazethapyr were separated by HPLC on Chiralcel OJ with a Hex/EtOH/HAc solution (75/25/0.5 by volume) (Zhou et al., 2009, Zhou et al., 2010), and their absolute configurations were confirmed as S-(+)-IM and R-(-)-IM by the octant rule as shown in Fig. 3-1.

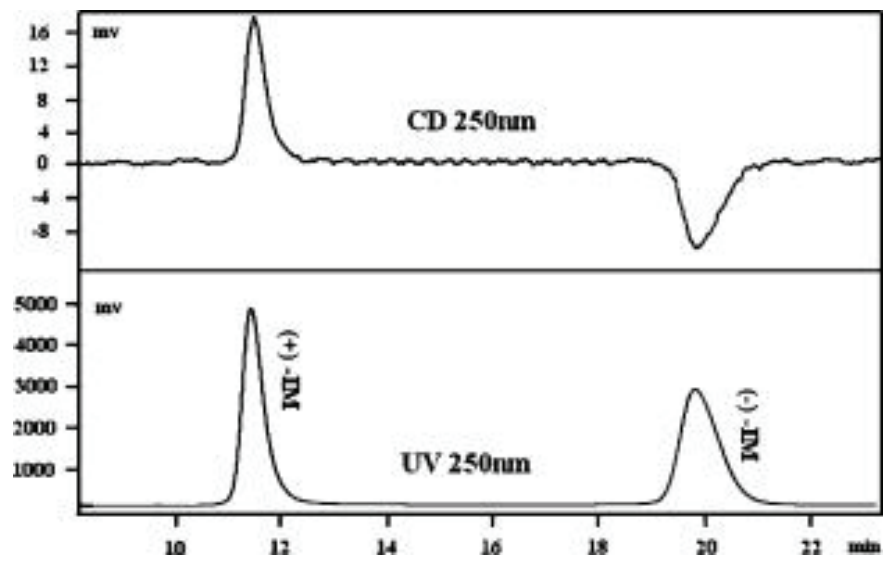

Fig. 3-1 HPLC chromatogram for the enantiomeric separation of imazethapyr on Chiralcel OJ. (Zhou et al., 2009)

\subsubsection{Enantioseparation of organophosphorus herbicides by HPLC}

Five chiral O-aryl O-alkyl N-alkylphosphoramidothioates herbicides were nearly baseline separated on a pirkle-type column OA-4700 (Chirex(S)-LEU \& (R)-NEA) by HPLC. The chromatographic elution order is $S>R$, and the S-enantiomer showed higher herbicidal activity than R-enantimer and/or racemates (Gao et al., 2000).

In another report by our group (Li et al., 2008), enantioselective separation and biological toxicity of a series of 1-(substituted phenoxyacetoxy)alkylphosphonates organophosphorous compounds (OPs compounds 1-5) were investigated on Chiralpak AD, Chiralpak AS, Chiralcel OD, and Chiralcel OJ. All the analytes investigated obtained baseline resolution $\left(R_{s}>1.5\right)$ on Chiralpak AD, which showed best chiral separation capacity. The acute aquatic toxicity of enantiomers and racemate to Daphnia magna (D. magna) were assessed. The in vivo assays showed that compound 3 was about 2-148.5 times more toxic than the other four analogues to D. magna. The racemates of compounds 3 and 5 showed intermediate toxicity compare to their enantiomers, while those of compounds 1, 2, and 4 showed synergistic or antagonistic effect. These results suggest that the biological toxicity of chiral OPs to nontarget organisms is enantioselective and therefore should be evaluated with their pure enantiomers.

\subsubsection{Enantioseparation of diphenyl ether herbicides by HPLC}

Ethoxyfen-ethyl and lactofen were separated using HPLC on polysaccharide CSPs by Zhou et al. (Wang et al., 2006, Tian et al., 2010, Hou et al., 2002, Diao et al., 2009). Enantioseparation of a novel herbicide ethoxyfen-ethyl was conducted on self-prepared CDMPC, and with the content of IPA in hexane in mobile phase decreased to $1 \%$, the resolution factors increased to 3.95 (Hou et al., 2002). The two enantiomers of the herbicide lactofen in soils were baseline 
separated and semiprepared on CDMPC using a normal phase HPLC (n-Hex/IPA 95/5). However, the baselined separation was not obtained on a self-prepared tris-(S)-1phenylethylcarbamate CSP (Wang et al., 2006). And lactofen also could be completely resolved $\left(\mathrm{R}_{\mathrm{s}} 2.07\right)$ by a reserved phase HPLC using $80 / 20 \mathrm{MeOH} / \mathrm{H}_{2} \mathrm{O}$ as mobile phase on ADMPC (Tian et al., 2010).

\subsection{Separation of chiral herbicides by GC}

GC is more suitable in analyzing because of its higher sensitivity, higher precision and less injection volume than HPLC system. Besides, contaminants and impurities usually can be separated from the analytes facilely by GC.

The most common chiral selectors used for GC are a group of CD and CD-derivatives. Enantiomers and diastereomers of some acetamide pesticides, alachlor, acetochlor, metolachlor, and dimethenamid, were separated using achiral and chiral high-resolution GC/MS (HRGC/MS) and chiral HPLC. Whereas alachlor is achiral, all other compounds are axial- and/or C-chiral and consist of two or four stereoisomers (enantiomers and diastereomers). Chiral HRGC using a $\beta-C D$ derivative showed varied resolution of diastereomers and/or enantiomers; achiral HRGC showed no resolution of diastereomers. Resolution of C-chiral enantiomers was easier than resolution of axial-chiral enantiomers (atropisomers) (Buser et al., 1995). And all four metolachlor isomers were identified by HRGC (Muller et al., 2001).

Leachate samples from a waste disposal site in Switzerland and groundwater samples downstream of the landfill were analyzed for residues of MCPP, DCPP, and 2,4-D esterified with 2,3,4,5,6-Pentafluorobenzyl (PFB) by means of enantiomer-specific GC-MS (Zipper et al., 1999, Zipper et al., 1998). The PFB esters of MCPP and DCPP were nearly baseline separated $\left(R_{s}=0.9\right)$ on a $15 \mathrm{~m}$ glass column $(0.25 \mathrm{~mm}$ i.d.) with an OV1701 polysiloxane phase containing $35 \%$ heptakis(2,3-dimethyl-6-tert-butyldimethylsilyl)- $\beta-C D$ (TBDM- $\beta-C D$ ) as the chiral selector.

A capillary column BGB-172 (20\% tert-butyldimethylsilyl- $\beta$-CD dissolved in 15\% diphenylpolysiloxane and 85\% dimethylpolysiloxane, GBG Analytik, Adliswil, Switzerland) was used for chiral GC separation of some herbicides by Liu et al. (Wen et al., 2004, Ma et al., 2006, Ma et al., 2009). DCPP methylated by diazomethane in water was separated and determined with a recovery about $90 \%$ (Wen et al., 2004). They also separated racmetolachlor and S-metolachlor in soil. However, the baseline separation was not achieved because of the presence of two chiral elements (asymmetrically substituted carbon and chiral axis nitrogen) (Ma et al., 2006). Furthermore, the enantiomeric separation of DCPPM was investigated by GC on BGB-172 and HPLC on Chiralcel OJ-H by this group. Baseline separation by both GC and HPLC was achieved (Ma et al., 2009).

\subsection{Separation of chiral herbicides by SFC}

As complementary analytical techniques for HPLC, packed-column SFC with sub- and/or supercritical fluid contains kinds of organic polar solvents is becoming a very popular chromatographic technique, for both analysis and small-scale preparation of optically pure chemicals and enantiomers identification, especially as CSPs are becoming easily available and widely applied. Nearly all the conventional HPLC CSPs could be applied in SFC mode except the chiral crown ester CSPs and the protein-based CSPs. Sub- and supercritical carbon dioxide $\left(\mathrm{CO}_{2}\right)$ remains the most commonly used fluid for SFC. Mechanistically, SFC 
plays a unique role acting as a bridge between GC and LC. Owing to the good diffusibility and low viscosity of supercritical fluids, column equilibration is accomplished more rapidly and enables faster flow rates in SFC than in HPLC. Besides, the higher diffusivity between mobile phase and CSPs yields greater efficiency (smaller plate heights) in resolving a sample.

Generally, SFC shows notable advantages and superior developmental potential on enantiomer separation. The advantages contain environmental friendly with low organic solvent consumption of mobile phase, simple method development, high efficiency on enantioseparation, low column pressure drop besides ease of coupling with chiral columns or MS. However, the high investment of SFC apparatus restricts its widespread application in enantioseparation. To date, the research about chiral herbicides separation by SFC is very limited. One herbicide example that can be resolved by SFC is the diasteriomeric compound metolachlor. The ability to quickly detect and identify metolachlor and its isomeric ratios in low concentration samples is possible, via SFC (Cole et al., 2007).

\subsection{Separation of chiral herbicides by CE}

$\mathrm{CE}$ is shown to be a simple, efficient, and inexpensive way with unique versatility to chiral separation because it can be applied to a wide variety of analytes flexibly with various modes. Hitherto, six separation modes of CE has been successfully used in chiral separation, including capillary zone electrophoresis (CZE), capillary electrochromatography (CEC), micellar electrokinetic chromatography (MECC or MEKC), capillary gel electrophoresis (CGE), capillary isoelectric focusing (CIEF), capillary isotachophoresis (CITP) (Li et al., 2010), where CZE, CEC and MEKC are the most successful CE modes. For the enantioseparation of chiral herbicides by $\mathrm{CE}, \mathrm{CD}$ and its derivatives are often added to the electrophoresis buffer as the chiral selectors.

Some chlorophenoxy acid herbicides and their enantiomers, 2,4-dichlorophenoxy-acetic acid (2,4-D), 2-(2,4-dichlorophenoxy)propionic acid (2,4-DP), 4-(2,4-dichlorophenoxy)butyric acid (2,4-DB), 4-chloro-2-methylphenoxyacetic acid (MCPA), were successfully swparated within 7 min by adding $4 \mathrm{mM} \mathrm{a-CD}$ and $1 \mathrm{mM} \beta-\mathrm{CD}$ in the buffer in CE (Hsieh et al., 1996). Analyzing the herbicides by $\mathrm{CE}$ posed the advantages of a high resolution, high separation efficiency and good reproducibility.

A novel, selective precolumn derivatization reaction was introduced and evaluated in the fluorescence labeling of phenoxy acid herbicides including 2,4-D, (2,4,5-trichlorophenoxy)acetic acid (2,4,5-T), 2-phenoxypropionic acid (2-PPA), MCPP, 2-(2-chlorophenoxy)propionic acid (2,2-CPPA), 2-(3-chlorophenoxy)propionic acid (2,3-CPPA), 2-(4chlorophenoxy)propionic acid (2,4-CPPA), DCPP and silvex with 7-aminonaphthalene-1,3disulfonic acid (ANDSA) by CE (Mechref et al., 1996a). The ANDSA-phenoxy acid herbicide enantiomers exhibited higher chiral resolution than their underivatized counterparts in the presence of $\mathrm{CD}$ in the running electrolyte. The best enantioselectivity was achieved when 2,3,6-tri-O-methyl- $\beta$-CD (TM- $\beta$-CD) was used as the chiral selector. Mixed CDs based on $\beta$ CD and TM- $\beta-C D$ proved to be the most effective as far as the enantiomeric resolution of the chiral analytes is concerned.

A novel chiral nonionic surfactant, namely octyl- $b$ - $D$-maltopyranoside (OM), was evaluated in chiral CE of fluorescently labeled phenoxy acid herbicides (Mechref et al., 1997a). The labeling of the analytes with 7-aminonaphthalene-1,3-disulfonic acid (ANDSA) permitted a concentration detection limit of $5 \times 10^{-10} \mathrm{M}$ using laser-induced fluorescence detection. The tagging of the phenoxy acid herbicides with ANDSA increased the hydrophobicity of the 
analytes, thus favoring an enhanced solubilization of the derivatized herbicides in the OM micellar phase. The net results of this effect were a much shorter analysis time and an improved enantiomeric resolution of the derivatives when compared to underivatized phenoxy acid herbicides. Baseline enantiomeric resolution of phenoxy acid herbicides including silvex, DCPP, MCPP, 2,4-CPPA, 2,3-CPPA, 2,2-CPPA and 2-PPA was attained without $30 \mathrm{~min}$ by $\mathrm{CE}$ using $200 \mathrm{mM}$ sodium phosphate buffer, $\mathrm{pH}$ 6.5, containing $60 \mathrm{mM} \mathrm{n}$ octyl- $\beta$-D-maltopyranoside (OM) (Mechref et al., 1996b). Silvex, DCPP, MCPP, 2,4-CPPA, 2,3-CPPA, 2,2-CPPA and 2-PPA were baseline separated except silvex by performing the separation at $10{ }^{\circ} \mathrm{C}$ and using $250 \mathrm{mM}$ sodium phosphate buffer, $\mathrm{pH} 6.5$, containing $50 \mathrm{mM}$ n-nonyl- $\beta$-glucopyranoside (NG) or $70 \mathrm{mM}$ n-octyl- $\beta$-glucopyranoside (OG) in CE. (Mechref et al., 1997b)

Vancomycin was used as chiral selector for the enantiomeric separation of several free acid herbicides including MCPP, fenoprop, DCPP, flamprop, haloxyfop, fluazifop, diclofop and fenoxaprop in CE (Desiderio et al., 1997a). The increase of vancomycin concentration caused a general increase of migration time, resolution and selectivity. Baseline resolution was achieved when a $6 \mathrm{mM}$ vancomycin was used. The CE separation of some herbicidal enantiomers was conducted applying 1-allylterguride as chiral selector (Ingelse et al., 1997). Baseline separation was shown for the enantiomers of fluazifop, halossifop and fenoxaprop, whereas the optical isomers of flamprop could be partially resolved using $100 \mathrm{mM} \beta$ alanine-acetate, $50 \mathrm{mM}$ TEA in $100 \% \mathrm{MeOH}$ supported with $100 \mathrm{mM}$ allyl-TER. Separation times are short compared to similar analyses, applying HPLC and a terguride CSP.

The enantiomers of a number of 2-aryloxypropionic acids and their ester and amide counterparts are readily separated on the commercially available $\beta$-GEM 1 and Whelk-O 1 CSPs. Of the analytes studied, the $\mathrm{N}, \mathrm{N}$-diethylamides typically show the greatest enantioselectivity. The enantiomers of several commercial herbicides from this family, including diclofop ethyl, devrinol, and MCPP were separated using the Whelk-O 1 CSP. $\beta$ Gem1 is а п-acceptor chiral stationary phase and is prepared by covalently bonding N-3,5dinitrobenzoyl-3-amino-3-phenyl-2-(1,1-dimethylethyl)-propanoate, to $5 \mu \mathrm{m}$ silica through an ester linkage. (Pirkle et al., 1997)

Baseline enantiomeric separation of a mixture of six pairs of phenoxypropionic acid herbicides (PPAHs) including 2,3-CPPA, 2,2-CPPA, 2,4-CPPA, 2(2,4-DCPPA), 2(2,4,5TCPPA) and 2-PPA was achieved in less than $30 \mathrm{~min}$ by $\mathrm{CE}$ with heptakis(6methoxyethylamine-6-deoxy)- $\beta$-CD $[\beta-\mathrm{CD}-\mathrm{OMe}(\mathrm{VII})]$ as chiral selector. The two most substituted herbicides [2(2,4-DCPPA) and 2(2,4,5-TCPPA)] were best resolved. One of the faster migrating antipodes of 2(2,4,5-TCPPA) co-eluted with one slower antipode of 2(2,4DCPPA) while both baseline separation was obtained run separately (Fig. 3-2) (Haynes et al., 1998).

DCPP and imazaquin was analyzed by CE as an anion (Jarman et al., 2005). DCPP was separated using $25 \mathrm{mM}$ sodium tetraborate (Na-TB), $\mathrm{pH} 8.5$, with $25 \mathrm{mM}$ trimethyl- $\beta-\mathrm{CD}$ as the chiral selector, while imazaquin was analyzed with $15 \mathrm{mM}$ dimethyl- $\beta-C D$ in $50 \mathrm{mM}$ acetate, $\mathrm{pH}$ 4.5. Furthermore, sodium hydrogen phosphate $(50 \mathrm{mM})$ at $\mathrm{pH} 10.1$ containing 30 $\mathrm{mM}$ hydroxypropyl- $\beta-\mathrm{CD}$ (HP- $\beta-\mathrm{CD})$ was found to be the suitable BGE to separate imazaquin enantiomers in field soils (Yi et al., 2007). In another report (Han et al., 2008), the two imazethapyr enantiomers were separated using $6 \%$ hydroxypropyl- $\beta-\mathrm{CD}$ as chiral selector in buffer at $\mathrm{pH} 11.0$. 


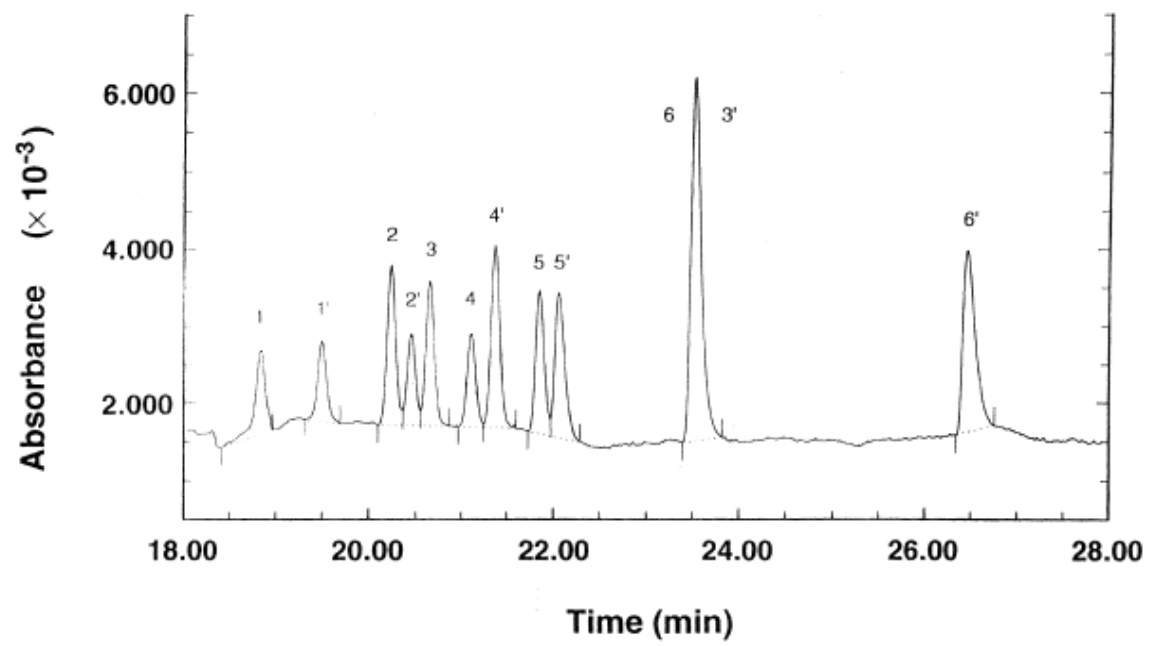

Fig. 3-2. Enantiomeric separation of a standard mixture of $12( \pm)$ PPAH enantiomers. The BGE contains $50 \mathrm{mM} \mathrm{NaH}_{2} \mathrm{PO}_{4}$ adjusted to $\mathrm{pH}$ 6; $3 \mathrm{mM} \beta$-CD-OMe (VII); applied voltage was $-15 \mathrm{kV},-25 \mu \mathrm{A}$; pressure injection $85 \mathrm{kPa}$ s; sample concentration $0.1 \mathrm{mg} / \mathrm{mL}$ in methanol-water (1:1, v/v). 1,1'=2-PPA, 2,2'=2,4-CPPA, 3, $3^{\prime}=2(2,4-\mathrm{DCPPA}), 4,4^{\prime}=2,2-\mathrm{CPPA}$, $5,5^{\prime}=2,3-\mathrm{CPPA}, 6,6^{\prime}=2(2,4,5-\mathrm{TCPPA})$. (Haynes et al., 1998)

\subsubsection{Separation of chiral herbicides by CZE}

The separation mechanism for CZE is based on the differences about the charge/mass ratios. Uncoated fused-silica capillary is filled with some type of electrolyte solution (running buffer or BGE). An electric field is applied to the capillary, and then cations go to the cathode, whereas anions migrate to the anode (Pico et al., 2003).

CD-CZE was applied successfully to the enantiomeric and isomeric separation of chiral herbicides.

Chiral separations of phenoxypropionic acid herbicides were achieved by adding a suitable CD-type chiral selector to the electrophoresis buffer (Nielen, 1993, Otsuka et al., 1998, Zerbinati et al., 2000). DCPP, fenoprop and MCPP, were baseline separated by the coupling of CE-MS with $20 \mathrm{mM}$ TM- $\beta-\mathrm{CD}$ in $50 \mathrm{mM}$ ammonium acetate (pH 4.6) (Otsukaet al., 1998). Separation of the four enantiomers of MCPP and DCPP was conducted on an ethylcarbonate derivative of $\beta-C D$ with three substituents per molecule, hydroxypropyl- $\beta-C D$ and native $\alpha-$ $\mathrm{CD}$ as chiral selectors in CZE. Complete resolution of the four optical isomers was obtained with10 mM ethylcarbonate- $\beta-\mathrm{CD}$ in the running buffer of $45 \mathrm{mM} \mathrm{NaH} \mathrm{PO}_{4}, \mathrm{pH} 5.6$ (Zerbinati et al., 2000).

The separation and detection of 2,4-dichlorophenoxyacetic acid and three optically active phenoxy acid herbicides (DCPP, MCPP and fenoprop) was investigated in CZE (Garrison et al., 1994). A $50 \mathrm{mM}$ acetate buffer at $\mathrm{pH} 4.5$ gave the best separation. Baseline separation of the two enantiomers of each three optically active herbicides, separately and in mixtures of the three, was accomplished by the addition of $25 \mathrm{mM}$ tri-O-methyl- $\beta-\mathrm{CD}$ to the acetate separation buffer. Di-O-methyl- $\beta-C D$ or $\alpha-C D$ separated enantiomers of DCPP and MCPP, but not those of fenoprop; $\beta-C D$ provided very little separation and $\gamma-C D$ gave no separation. 
Several chiral herbicides, bromacil, chlorbufam, ethofumesate, imazapyr, flampropisopropyl, flamprop-free acid, fluazifop-free acid, haloxyfop-free acid, and napropamide, were separated in CZE (Desiderio et al., 1997b). Different $\beta$-CD derivatives were investigated for chiral separations and among them the negatively charged sulfobutyl ether $\beta-C D$ (SBE- $\beta-C D$ ) proved to be effective for the stereoselective resolutions of the investigated herbicides. Addition of SBE- $\beta-\mathrm{CD}(5-50 \mathrm{mg} / \mathrm{mL})$ to the buffer at $\mathrm{pH} 9$ resulted in a general increase of migration times as well as resolution. A CD concentration as low as 5 $\mathrm{mg} / \mathrm{mL}$ was effective to completely resolve napropamide and ethofumesate enantiomers.

The enantiomeric and isomeric separation of imazaquin, diclofop and imazamethabenz was investigated in CD-CZE (DM- $\beta-C D, T M-\beta-C D$ and HP- $\gamma-C D)$ (Penmetsa et al., 1997). The enantiomers of imazaquin and diclofop, and the isomers of imazamethabenz could be resolved with $R_{s} \geq 1.5$ (Fig. 3-3). By employing mixed CDs in the running buffer, the three herbicides were simultaneously separated in a single run (Fig. 3-4).

The separation of DCPP was reported in CZE with $\alpha-, \beta$ - and $\gamma$-CDs as well as their chemical derivatives $C_{6}$-capped- $\beta-C D$, ethylcarbonate- $\beta-C D$, ethylcarbonate- $\gamma-C D$, methyl- $\beta-C D$ and hydroxypropyl- $\beta-C D$ as chiral selectors. Several of the investigated CDs allowed DCPP enantiomer resolution. In particular, a newly synthesised ethylcarbonate derivative of $\beta-C D$ showed the best enantiomer resolution properties among the tested compounds. (Zerbinati et al., 1998)

Biological degradation of acetanilide herbicides in soil results in the formation of the ethanesulfonic acid (ESA) and oxanilic acid (OXA) derivatives. These molecules exist in two (alachlor), four (acetochlor), and eight (metolachlor) stereoisomeric forms. Using $\mathrm{\gamma}-\mathrm{CD}$ as chiral selector in CZE, complete separation of all four isomers of enantiomerically enriched (5S)-metolachlor OXA was achieved. The enantiomers of acetochlor ESA, acetochlor OXA, and racemic metolachlor OXA were partially separated. (Aga et al., 1999)

CZE was used for the chiral and mutual separation of four phenoxy acid herbicides, fenoprop, dicloprop, MCPP and 2,4-DB, using highly sulphated CD (HSCD) in the buffer. The $\mathrm{CE}$ runs were performed with reverse polarity (anode in the outlet vial) using the acidic ammonium formate buffer ( $20 \mathrm{mmol}, \mathrm{pH} 3.0)$. The chiral separation of dicloprop and MCPP were achieved with a-HSCD but it was not able to resolve fenoprop. With $\beta$-HSCD the required base line separation was achieved. The limit of detection $(\mathrm{S} / \mathrm{N}=3)$ achieved in present case is $0.15 \mathrm{ppm}$ for fenoprop, $0.14 \mathrm{ppm}$ for dicloprop and MCPP and $0.11 \mathrm{ppm}$ for 2,4-DB. (Malik et al., 2009)

Soil samples taken from a field plot at increasing time intervals after application of Foxtril, a commercial herbicide formulation, were solvent-extracted and analyzed for total DCPP by $\mathrm{CZE}$, using an acetate buffer at $\mathrm{pH}$ 4.7. TM- $\beta-\mathrm{CD}$, was then added to the buffer as chiral reagent to effect separation of the (+)- and (-)-enantiomers of DCPP. Baseline resolution allowed calculation of relative concentrations (enantiomer ratios) of the two isomers. The hydrolysis product [methyl 2-nitro-5-(2,4-dichlorophenoxy) benzoic acid] of bifenox methyl ester, another herbicide component of Foxtril, was detected in the soil samples taken at 17 and $31 \mathrm{~d}$. The acetate separation buffer was $50 \mathrm{mM}$ at $\mathrm{pH} 4.65$ and was composed as follows: $0.05 \mathrm{M}$ glacial acetic acid: $0.05 \mathrm{M}$ sodium acetate, 1:1, v:v. The cyclodextrincontaining buffer for enantiomeric separation was prepared by dissolving TM- $\beta-C D$ in the acetate separation buffer to a final concentration of $25 \mathrm{mM}$ cyclodextrin. (Garrison et al., 1996) 

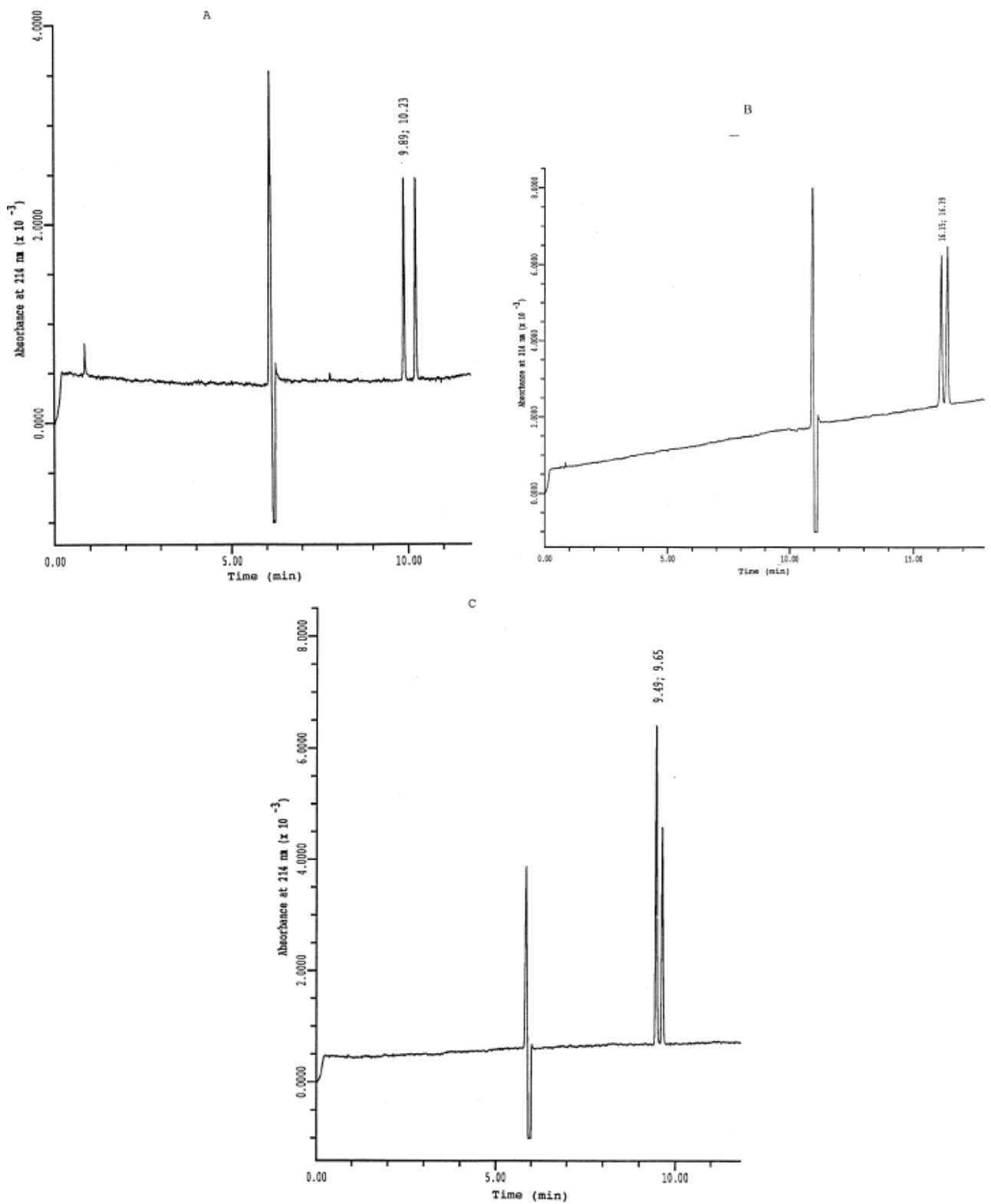

Fig. 3-3. Separation of (A) imazaquin enantiomers, (B) diclofop enantiomers and (C) imazamethabenz isomers (9.49 $\mathrm{min}$, para and $9.65 \mathrm{~min}$, meta isomers). Analysis conditions: $57 \mathrm{~cm}(50 \mathrm{~cm}$ to detector $) \times 50 \mu \mathrm{m}$ I.D. capillary column; pressure injection $(2 \mathrm{~s}=2.4 \mathrm{nl}) ; 25 \mathrm{kV}$ $(35 \mu \mathrm{A}) ; 214 \mathrm{~nm}$ UV absorbance. Buffer: (A) $50 \mathrm{mM}$ sodium acetate $+10 \mathrm{mM}$ DM- $\beta$-CD buffer, $\mathrm{pH} 4.6$, (B) $50 \mathrm{mM}$ sodium acetate $+10 \mathrm{mM}$ TM- $\beta$-CD buffer, $\mathrm{pH} 3.6$ and (C) $50 \mathrm{mM}$ sodium acetate $+10 \mathrm{mM}$ TM- $\beta-\mathrm{CD}$ buffer, $\mathrm{pH} 4.6$. 


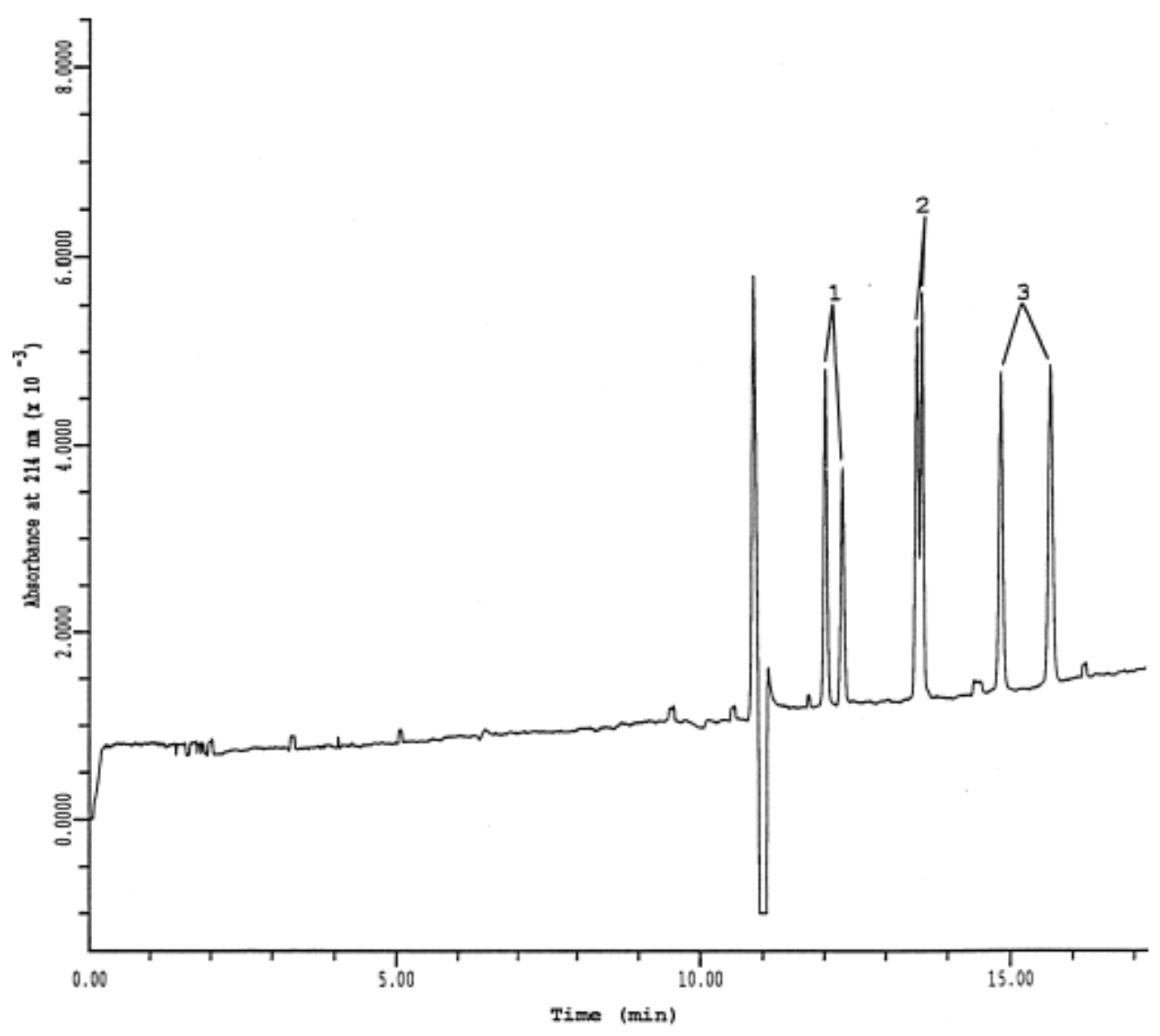

Fig. 3-4. Simultaneous separation of herbicides using mixed cyclodextrins. (1) Imazamethabenz isomers, (2) diclofop enantiomers and (3) imazaquin enantiomers. Analysis conditions: $57 \mathrm{~cm}(50 \mathrm{~cm}$ to detector $) \times 50 \mu \mathrm{m}$ I.D. capillary column; pressure injection $(2 \mathrm{~s}=2.4 \mathrm{nl}) ; 50 \mathrm{mM}$ sodium acetate $+10 \mathrm{mM}$ DM- $\beta-C D+10 \mathrm{mM}$ TM- $\beta$-CD buffer, pH 3.6; 25 kV $(35 \mu \mathrm{A}) ; 214$ nm UV absorbance. (Penmetsa et al., 1997)

\subsubsection{Separation of chiral herbicides by CEC}

CEC utilises a stationary phase rather than a micellar pseudo-stationary one. CEC is a hybrid technique that couples the selectivity of LC and the separation efficiency of CE. Both charged and uncharged compounds can be separated effectively using CEC.

A series of herbicide molecules (haloxyfop, fluazifop, fenoxaprop, and flamprop free acids, diclofop, MCPP, DCPP, fenoprop, 2-PPA) were separated using a CSP derived from an LRNA aptamer by CEC after binding to biotin and grafting upon streptavidin-modified porous glass beads. (Andre et al., 2006)

A porous monolithic chiral column was prepared by in situ copolymerization of glycidyl methacrylate, methyl methacrylate and ethylene glycol dimethacrylate in the presence of formamide and 1-propanol as the porogen solvents to analyze the DCPP enantiomers. 
Subsequently, the epoxide groups at the surface of the monolith were reacted with (+)-1-(4aminobutyl)-(5R,8S,10R)-terguride as the chiral selector. Optimum conditions for the herbicide resolution by CEC were found using mobile phases consisting of HAc/TEA mixtures in $\mathrm{MeCN}: \mathrm{MeOH}(9: 1 \mathrm{v} / \mathrm{v})$. Under these conditions fully separation of DCPP enantiomers in the presence of clofibric acid (internal standard) was achieved in about 5 min. (Messina et al., 2007)

A silica based monolithic capillary column derivatized with O-9-(tert-butylcarbamoyl) quinidine was prepared for CEC enantiomer separation of chiral 2-aryloxypropionic acid herbicides including inter alia DCPP, MCPP and fenoprop. Reasonable baseline separations of enantiomers were accomplished for all analytes after optimization of relevant mobile phase parameters in the anion-exchange CEC system, and the separations were comparable to such obtained on an optimized high density quinidine-carbamate modified organic polymer monolith column. (Buchinger et al., 2009)

\subsubsection{Separation of chiral herbicides by MEKC}

MEKC separation mechanism is based on the differences between interactions of analytes with micelles present in the separation buffer, which can easily separate both charged and neutral solutes with either hydrophobic or hydrophilic properties.

Silvex was separated partially with $50.0 \mathrm{mM}$ N,N-bis-(3-Dgluconamidopropyl)deoxycholamide as chiral selector, $400.0 \mathrm{mM}$ borate treated fused-silica capillaries at $\mathrm{pH} 10.0,15^{\circ} \mathrm{C}$, voltage $20.0 \mathrm{kv}$ in MEKC. (Mechref et al., 1996c)

Enantiomeric ratios of methyl esters of phenoxy acids herbicides and an acetamide herbicide metolachlor were being measured. Each of six CD, $a-C D, \beta-C D, \gamma-C D$, hydroxypropyl- $\beta-C D$, dimethyl- $\beta-C D$ and trimethyl- $\beta-C D$, were then added to the borate-SDS buffer, with and without the organic modifier, to test for separation of the non-chiral compounds and the enantiomers of the chiral racemates by CD-MEKC. $\gamma-\mathrm{CD}$ with $\mathrm{MeOH}$ modifier allowed baseline separation of the three phenoxy acid methyl esters and of fenoprop methyl ester, but none of the CDs separated the enantiomers of MCPP and DCPPM. Finally, attempts were made to separate the four enantiomers of the herbicide metolachlor; three of the enantiomers were separated by $\gamma-C D$ with methanol. (Schmitt et al., 1997)

The enantiomeric resolution of chiral phenoxy acid herbicides was performed by MEKC using several neutral and charged CD as chiral pseudophase (CD-MEKC). Among the CDs tested, HP- $\beta-\mathrm{CD}$ was found to be the most appropriate for the enantioseparation of phenoxy acids. The use of a $50 \mathrm{mM}$ electrolyte solution in ammonium formate at $\mathrm{pH} 5$ containing 15 $\mathrm{mM} \mathrm{HP}-\beta-\mathrm{CD}$ and a temperature of $40{ }^{\circ} \mathrm{C}$ enabled the enantiomeric resolution of four of the six phenoxy acids investigated (2-PPA, 2,3-PPA, 2,4-CPPA, and 2-(2,4-DCPPA)) obtaining migration times ranging from 9 to $15 \mathrm{~min}$. Mixtures of the two phenoxy acids not enantiomerically resolved (2-(4-chlorophenoxy)-2-methylpropionic acid and 2-(2,4,5trichlorophenoxy)propionic acid) and up to three of the phenoxy acids enantiomerically resolved were separated in about $15 \mathrm{~min}$. (Martin-Biosca et al., 2001)

CD-MEKC was applied to the enantioseparation of thiobencarb sulfoxide, which is produced by S-oxygenation of thiobencarb, using $\mathrm{\gamma}-\mathrm{CD}$ together with sodium dodecyl sulfate. The optimum running conditions were found to be $20 \mathrm{mM}$ phosphate $5 \mathrm{mM}$ borate buffer ( $\mathrm{pH}$ 8.5) containing $60 \mathrm{mM}$ hydroxypropyl- $\gamma-\mathrm{CD}$ and $100 \mathrm{mM}$ sodium dodecyl sulfate with an effective voltage of $+20 \mathrm{kV}$ at $20^{\circ} \mathrm{C}$ using direct detection at $220 \mathrm{~nm}$ with resolution $\left(\mathrm{R}_{\mathrm{s}}\right)$ approximately 1.7 . (Kodama et al., 2002) 


\subsection{Separation of chiral herbicides by other chromatographic methods}

A preparative enantiomer separation method of DCPP was developed utilizing a purposefully designed, highly enantioselective chiral stationary phase additive (CSPA) cinchona-derived chiral seleector derived from bis-1,4-(dihydroquinidinyl)phthalazine in centrifugal partition chromatography (CPC). A solvent system consisting of $10 \mathrm{mM}$ CSPA in methyl tert-butyl ether and $100 \mathrm{mM}$ sodium phosphate buffer $(\mathrm{pH}$ 8.0) was identified as a suitable stationary/mobile-phase combination. Complete enantiomer separations of up to $366 \mathrm{mg}$ of racemic DCPP could be achieved, corresponding to a sample load being equivalent to the molar amount of CSPA employed. Comparison of the preparative performance characteristics of the CPC protocol with that of a HPLC separation using a silica-supported bis-1,4-(dihydroquinidinyl)phthalazine CSP revealed comparable loading capacities for both techniques but a significantly lower solvent consumption for CPC. Given that further progress in instrumental design and engineering of dedicated, highly enantioselective CSPAs can be achieved, CPC may offer a viable alternative to CSP-based HPLC for preparative-scale enantiomer separation. (Gavioli et al., 2004)

\section{Enantioselective herbicidal activity and toxicity of herbicide enantiomers}

For the amide herbicides, the product enantiomerically enriched with the herbicidally active 1'S-metolachlor (aSS, aRS) has replaced the racimate worldwide after 2004 (Muller et al., 2001). S-metolachlor was more toxic to $C$ pyrenoidosa than rac-metolachlor, and the catalase activity of $\mathrm{C}$ pyrenoidosa treated by S-metolachlor was higher than that exposed to racmetolachlor (Liu et al., 2009). And enantioselective degradation and/or interconversion for metolachlor was determined, S-metolachlor degraded faster in soil than rac-metolachlor (Ma et al., 2006, Kurt-Karakus et al., 2010). After 42-day incubation, 73.4\% of rac-metolachlor and $90.0 \%$ of S-metolachlor were degraded. However, due to the absence of biological processes the degradation process in sterilized soil showed no enantioselectivity. The results indicated that enantioselective degradations could greatly affect the environmental fate of metolachlor and should be considered when the environmental behavior of these compounds was assessed. Napropamide is a highly active preemergence herbicide whose R-enantiomer has high phytocidal activity to unifacial-leaf and broad-leaf weeds. It was found that Rnapropamide was about eight fold more active than S-napropamide, and two more active than rac-napropamide (Chan et al., 1975). The green alga Scenedesmus acutus growth was strongly inhibited and fatty acid was desaturated by S-alachlor and S-dimethenamid while the R isomer had no effect (Couderchet et al., 1997). Furthermore, the comparable biological activities of dimethenamid and alachlor indicate that this target is common to both $\mathrm{N}$ phenyl and $\mathrm{N}$-thienyl chloroacetamide herbicides.

Enantioselective herbicidal activity and toxicity of the phenoxy herbicides has been reported profoundly and roundly. The in vivo inhibition of R-(+)- and S-(-)-diclofop-methyl affected on root growth was hardly enantioselective (Shimabukuro et al., 1995), while in a report by Liu et al. (Ye et al., 2009), the S-diclofop acid was more toxic to leaves and the R-diclofop acid was more toxic to roots of rice Xiushui 63 seedlings. Furthermore, absorption and translocation to the leaf axil of the two-leaf stage plants of diclofop-methyl enantiomers were similar in both susceptible and resistant biotypes, while the rate of metabolism was increased 1.5-fold in this resistant biotype compared to the susceptible (Maneechote et al., 1997). More, the herbicidally inactive S-(-)-enantiorners of both diclofop-methyl and diclofop were similar to or higher than the corresponding R-(+)-forms in toxicity to algae, 
depending on specific species. Although no enantiomeric conversion occurred for diclofopmethyl and diclofop, the difference in the enantioselective degradation of these herbicides observed in algae cultures suggested that their application forms were an important factor determining their enantioselective environmental behavior. It was concluded that the enantioselective degradation of diclofop in algae cultures was governed primarily by the facilitated uptake by algae, whereas the enantioselective toxicity was primarily governed by the passive uptake (Cai et al., 2008). And it was proved that the S-diclofop-methyl dissipated faster than R-diclofop-methyl while the generation and degradation rates of S-diclofop were higher than R-enantiomer in the plant by Zhou et al. (Gu et al., 2010). However, in a former report of Zhou et al. (Diao et al., 2010a), it was found that the degradation of diclofop-methyl in two soils was not enantioselective while the degradation of diclofop was enantioselective under both aerobic and anaerobic conditions, and the S-(-)-diclofop was preferentially degraded, resulting in relative enrichment of the R-(+)-form. To haloxyfop ethoxyethyl ester, the S-form was degraded faster than R-form (the enantiomeric fraction of R-form was about 72\%) (Desiderio et al., 1997a).

Phenoxypropionic acid (PPA) derivatives are widely used in agriculture as selective herbicides. R-enantiomer of PPAs is known for its herbicidal activity while S-isomer is inactive as herbicidal agent (Buser et al., 1997a). A large number of papers have discussed the enantioselectivity of DCPP and MCPP (Zipper et al., 1999, Rugge et al., 2002, Schneiderheinze et al., 1999, Zipper et al., 1998, Ma et al., 2009, Jarman et al., 2005, Garrison et al., 1996, Messina et al., 2007, Kurt-Karakus et al., 2010, Buser et al., 1997b, Muller et al., 1997, Harrison et al., 2003, Williams et al., 2003, Wen et al., 2009, Wen et al., 2010), thereinto Bidleman et al. (Kurt-Karakus et al., 2010) reviewed the concentrations and stereoisomer ratios of DCPP, MCPP and metolachlor. Mostly, the S-enantiomer of these herbicides degraded faster than the R-enantiomer (Zipper et al., 1999, Zipper et al., 1998, Garrison et al., 1996, Messina et al., 2007, Buser et al., 1997b, Muller et al., 1997). Enantioselective microbial degradation increased the enantiomeric ratio of R- to S-MCPP during groundwater passage of the landfill leachate (Zipper et al., 1998). The S-enantiomers of MCPP, DCPP and 2,4-D were preferentially degraded under aerobic conditions (Zipper et al., 1999). The S-(-)-DCPP degraded significantly faster $\left.\left(\mathrm{t}_{1 / 2}\right)=4.4 \mathrm{~d}\right)$ than the $\mathrm{R}-(+)$-isomer $\left(\mathrm{t}_{1 / 2}=8.7 \mathrm{~d}\right)$ in soil (Garrison et al., 1996). No preferential degradation of the R- and S-enantiomers of MCPP and of DCPP took place in an aerobic field-injection experiment (Rugge et al., 2002, Jarman et al., 2005). However, in the nitrate-reducing microcosm S-MCPP did not degrade but R-MCPP degraded with zero order kinetics at $0.65 \mathrm{mg} /(\mathrm{L} \cdot \mathrm{d})$ to produce a stoichiometric equivalent amount of 4-chloro-2-methylphenol while no biodegradation of MCPP was observed in the methanogenic, sulphate-reducing or iron-reducing microcosms. And in aerobic conditions S- and R-MCPP degraded with zero order kinetics at rates of 1.90 and $1.32 \mathrm{mg} /(\mathrm{L} \cdot \mathrm{d})$, respectively (Harrison et al., 2003, Williams et al., 2003). Chitosan also changed the enantioselective bioavailability of DCPP (Wen et al., 2010). The dissipation of S-enantiomer in Chlorella pyrenoidosa culture media without chitosan was faster than that of the herbicidally active R-enantiomer, whereas it was inversed to R-enantiomer being faster than S-enantiomer when chitosan was added into the media. In the absence of chitosan, the toxicity of R-enantiomer to Chlorella pyrenoidosa was more potent than that of the Senantiomer. On the contrary, in the presence of chitosan, R-enantiomer was less toxic than Senantiomer. R-DCPP interacted with penicillium expansum alkaline lipase the strongest, followed by Rac-DCPP, while S-DCPP had the weakest interaction (Wen et al., 2009). RDCPPM was preferentially degraded over the S-DCPPM in different $\mathrm{pH}$ solutions (Ma et al., 2009). 
Racemic mixtures of 2,4-DP and MCPP were applied to three species of turf grass, four species of broadleaf weeds, and soil. Both herbicides were degraded more quickly and completely by plants than by soil microbes. Preferential degradation of the S-(-)-enantiomer of each herbicide was observed in most species of broadleaf weeds and soil, while the degradation in all species of grass occurred without enantioselectivity. The biodegradation in all systems appeared to follow pseudo first-order kinetics will the fastest degradation occurring in broadleaf weeds, followed by the grasses. The slowest degradation was observed in soil. (Schneiderheinze et al., 1999)

Enantioselective herbicidal activity and degradation of imidazolinone herbicides has been reported recently. Imazaquin exhibited nonselective enantiomer loss over its 3 months of incubation time, which could have been due to abiotic or nonselective microbial reactions (Jarman et al., 2005). However, in another report (Yi et al., 2007), the degradation rates of the two imazaquin enantiomers were slightly different, and the $\mathrm{pH}$ of the soil, combined with the moisture content in the soil, had a strong influence on the rate of degradation. And the first enantiomer imazethapyr-I, eluted by $C E$ using $6 \%$ hydroxypropyl- $\beta-C D$ as chiral selector in buffer at $\mathrm{pH} 11.0$, degraded at a higher rate when compared with imazethapyr-II (Han et al., 2008). The R-(+)-enantiomer of all three herbicides, imazapyr, imazethapyr and imazaquin, which has greater herbicidal activity (up to eight times), was found to degrade faster than the less active S-(-)-enantiomer (Ramezani et al., 2010). Generally, the R former of imidazolinones was more active than $S$ former. Imazethapyr inhibits elongation of primary roots and shoots, and reduces the number of adventitious roots and the density of root hairs. The maximal root relative inhibition rate reached $80.4 \%, 67.0 \%$, and $73.5 \%$ for $\mathrm{R}-(-)-$ imazethapyr, S-(+)-imazethapyr and (+/-)-imazethapyr at the concentration of $0.5 \mathrm{mg} / \mathrm{L}$, respectively, and the maximal shoot relative inhibition rate reached $77.7 \%, 26.9 \%$, and $61.7 \%$, respectively (Qian et al., 2009). The inhibition abilities of (+/-)-imazethapyr to the root growth of maize seedlings was between S-(+)- and R-(-)-imazethapyr (Zhou et al., 2009). Moreover, imazethapyr enantiomers enantioselectively suppressed the in vitro and in vivo acetolactate synthase (ALS) activity of maize leaves (Zhou et al., 2010). The in vivo ALS activity study showed only a 2-fold difference between R-(-)-imazethapyr and S-(+)imazethapyr, while the in vitro study showed that the difference in inhibition between the enantiomers fell sharply as concentration increased. At the lowest concentration of $40 \mu \mathrm{g} / \mathrm{L}$, R-(-)-imazethapyr appeared 25 times more active than S-(+)-imazethapyr, but only 7 times at $200 \mu \mathrm{g} / \mathrm{L}$. At the highest concentration of $25 \mathrm{mg} / \mathrm{L}$, in vitro ALS activity was almost completely inhibited by S-(+)-, R-(-)- and (+/-)-imazethapyr, there was only 1.1 times differences between S-(+)- and R-(-)-imazethapyr.

Thiobencarb was treated with a rat liver microsomal fraction containing cofactors (known as S9mix) (Kodama et al., 2002). The ratio between (+)- and (-)-thiobencarb sulfoxide was found to be 15:85. It was also found that the ratio between $(+)$ and (-)-thiobencarb sulfoxide produced in soil spiked with thiobencarb was 3:7. These results indicated marked enantioselectivities for these metabolisms. The activities of thiobencarb, (+)- and (-)thiobencarb sulfoxides on $5 a$-dihydrotestosterone- and $17 \beta$-estradiol-induced transcriptions were also investigated. Thiobencarb and (+)-thiobencarb sulfoxide did not show any activities, (-)-thiobencarb sulfoxide showed significant anti-estrogenic and anti-androgenic activities, suggesting that thiobencarb sulfoxide can act as both an enantioselective antiestrogen and an enantioselective anti-androgen.

Racemic and the enantiopure S-(+)- and R-(-)-lactofen were incubated under aerobic and anaerobic conditions. The data from sterilized controls indicated that the dissipation of 
lactofen was biological. The dissipation was shown to be enantioselective with S-(+)enantiomer being degraded faster than the R-(-)-enantiomer, resulting in residues enriched with R-(-)-lactofen when the racemic compound was incubated. Lactofen was configurationally stable in soil, showing no interconversion of S-(+)- to R-(-)-enantiomer and vice versa (Diao et al., 2009). The enantioselective degradation of lactofen enantiomers was proved in a report by Zhou et al. (Diao et al., 2010b). In sediments, S-(+)-lactofen or S$(+)$-desethyl lactofen was preferentially degraded, resulting in relative enrichment of the R(-)-form. Lactofen and desethyl lactofen were both configurationally stable in sediment, showing no interconversion of S- to R-enantiomers or vice versa. Furthermore, the acute toxicities of lactofen and desethyl lactofen enantiomers to Daphnia magna were enantioselective. The calculated LC50 values of S-(+)-, rac-, and R-(-)-lactofen were 17.689, 4.308 , and $0.378 \mu \mathrm{g} / \mathrm{mL}$, respectively, and the calculated LC50 values of S-(+)-, rac-, and R-()-desethyl lactofen were 21.327, 13.684, and $2.568 \mu \mathrm{g} / \mathrm{mL}$, respectively.

2-a-substituted benzylamino-4-substituted-amino-6-chloro-1,3,5-triazines are herbicidal compounds showing leaf-burning and/or growth inhibition with concomitant greening and stunting. The test compounds inhibited root growth due to interference with a system or systems other than photosynthesis. 4-(R)-sec-butylamino-2-(a,a-dimethylbenzyl)amino-6chloro-1,3,5-triazine showed the highest inhibitory activity, and 4-methylamino-2-(R)-amethylbenzylamino-6-chloro-1,3,5-triazine was second. The chiral requirement for a strong inhibition of root growth was the R-configuration, contrasting with the requirement for the S-configuration for an inhibition of photosystem II. (Omokawa et al., 1992)

Differential chiral responses including enantioselectivity and cross intergenus response on root growth between Oryza and Echinochloa plants against optical active a-methylbenzyl ptolylureas were indicated. Rice was more affected by the R-enantiomers and barnyard miller by the S-enantiomers (Omokawa et al., 2001). Plants of the tribe Oryzeae respond enantioselectively and homogeneously to optically active 1-(C)-methylbenzyl-3-p-tolylurea (MBTU) in root growth inhibition. The root growth of the genus Oryza was inhibited more by R-MBTU than by S-MBTU (Omokawa et al., 2004).

\section{Conclusions}

Over the last several decades, the enantioseparation of chiral herbicides has been widely studied and has made a great contribution for studying their stereoselectivity in biological target activity and non-target toxicity. The direct chromatographic separation approaches play a leading role in separation of chiral herbicides. HPLC combined with CSPs shows its superiority for the enantiomer analysis and enantiomer preparation of many common herbicides especially for the group of amide herbicides, phenoxy herbicides and imidazolinone herbicides. GC is powerful in the determination while CE with diversified modes is also useful for its maneuverability. The application of herbicides separation by SFC is relatively limited.

Many herbicides, related to amide herbicides, phenoxy herbicides and imidazolinone herbicides and so on, have shown the enantioselective herbicidal activity and phytotoxicity with their enantiomers. Many chiral herbicides have been commercialized with the pure enantiomer such as S-metolachlor, quizalofop-P-ethyl, haloxyfop-P-methyl, fluazifop-Pbutyl, (R)-napropamide etc.. Additionally, more work should be conducted on researching enantioselectivity and environmental fate of herbicides. 


\section{References}

Wang, P., Liu, D. H., Lei, X. Q., Jiang, S. R., Zhou, Z. Q., (2006), Enantiomeric separation of chiral pesticides by high-performance liquid chromatography on an amylose tris(S)-1-phenylethylcarbamate chiral stationary phase, Journal of Separation Science, 29, pp. 265-271.

Hamper, B. C., Dukesherer, D. R., Moedritzer, K., (1994), Analytical and preparative separation of the enantiomers of pyrazole phenyl ether herbicides on three chiral stationary phases, Journal of Chromatography A, 666, pp. 479-484.

Kodama, S., Yamamato, A., Matsunaga, A., Okamura, K., Kizu, R., Hayakawa, K., (2002), Enantioselective analysis of thiobencarb sulfoxide produced by metabolism of thiobencarb by hydroxypropyl- $\gamma$-cyclodextrin modified micellar electrokinetic chromatography, Journal of Separation Science, 25, pp. 1055-1062.

Muller, M. D., Poiger, T., Buser, H. R., (2001), Isolation and identification of the metolachlor stereoisomers using high-performance liquid chromatography, polarimetric measurements, and enantioselective gas chromatography, Journal of Agricultural and Food Chemistry, 49, pp. 42-49.

Polcaro, C. M., Berti, A., Mannina, L., Marra, C., Sinibaldi, M., Viel, S., (2004), Chiral HPLC resolution of neutral pesticides, Journal of Liquid Chromatography $\mathcal{E}$ Related Technologies, 27, pp. 49-61.

Buser, H. R., Muller, M. D., (1995), Environmental Behavior Of Acetamide Pesticide Stereoisomers .1. Stereoselective And Enantioselective Determination Using Chiral High-Resolution Gas-Chromatography And Chiral High-Performance LiquidChromatography Environmental Science \& Technology, 29, pp. 2023-2030.

Peng, W., Shu-Ren, J., Dong-Hui, L., Ping, W., (2005), Chiral Recognition of Acetochlor Enantiomers, Chinese Journal of Pesticides, 44, pp. 113-114.

Saito, K., Yato, M., Ito, T., Iwasaki, Y., Ito, R., Matsuki, Y., Nakazawa, H., (2008), Verification of the need for optical purity measurement of chiral pesticide standards as agricultural reference materials, Accreditation and Quality Assurance, 13, pp. 373-379.

Chen, S. W., Cai, X. Y., Xi, M., Zhang, A. P., Liu, W. P., (2006), Characterization of napropamide enantiomers by $\mathrm{CD}$ and determination of the enantiomeric ratios in water, Spectroscopy and Spectral Analysis, 26, pp. 1649-1652.

Zhou, Y., Zhang, S.-H., Liu, W.-P., Chen, Y.-H., Ye, L., (2006), Enantioresolution and study of thermodynamical property of napropamide by high performance liquid chromatography, Chinese Journal of Pesticide Science, 8, pp. 260-264.

Tian, Q., Lv, C. G., Ren, L. P., Zhou, Z. Q., (2010), Direct Enantiomeric Separation of Chiral Pesticides by LC on Amylose Tris(3,5-dimethylphenylcarbamate) Stationary Phase under Reversed Phase Conditions, Chromatographia, 71, pp. 855-865.

Padiglioni, P., Polcaro, C. M., Marchese, S., Sinibaldi, M., Flieger, M., (1996), Enantiomeric separations of halogen-substituted 2-aryloxypropionic acids by high-performance liquid chromatography on a terguride-based chiral stationary phase, Journal of Chromatography A, 756, pp. 119-127.

Riering, H., Sieber, M., (1996), Covalently bonded permethylated cyclodextrins, new selectors for enantiomeric separations by liquid chromatography, Journal of Chromatography A, 728, pp. 171-177.

Zipper, C., Bolliger, C., Fleischmann, T., Suter, M. J. F., Angst, W., Muller, M. D., Kohler, H. P. E., (1999), Fate of the herbicides mecoprop, dichlorprop, and 2,4-D in aerobic and 
anaerobic sewage sludge as determined by laboratory batch studies and enantiomer-specific analysis, Biodegradation, 10, pp. 271-278.

Rugge, K., Juhler, R. K., Broholm, M. M., Bjerg, P. L., (2002), Degradation of the (R)- and (S)enantiomers of the herbicides MCPP and dichlorprop in a continuous fieldinjection experiment, Water Research, 36, pp. 4160-4164.

Berthod, A., Chen, X. H., Kullman, J. P., Armstrong, D. W., Gasparrini, F., D'Acquarica, I., Villani, C., Carotti, A., (2000a), Role of the carbohydrate moieties in chiral recognition on teicoplanin-based LC stationary phases, Analytical Chemistry, 72, pp. 1767-1780.

Berthod, A., Yu, T., Kullman, J. P., Armstrong, D. W., Gasparrini, F., D'Acquarica, I., Misiti, D., Carotti, A., (2000b), Evaluation of the macrocyclic glycopeptide A-40,926 as a high-performance liquid chromatographic chiral selector and comparison with teicoplanin chiral stationary phase, Journal of Chromatography A, 897, pp. 113-129.

Lin, K. D., Cai, X. Y., Chen, S. W., Liu, W. P., (2006), Simultaneous determination of enantiomers of rac-diclofop methyl and rac-diclofop acid in water by high performance liquid chromatography coupled with fluorescence detection, Chinese Journal of Analytical Chemistry, 34, pp. 613-616.

Gu, X., Lu, Y. L., Wang, P., Dang, Z. H., Zhou, Z. Q., (2010), Enantioselective degradation of diclofop-methyl in cole (Brassica chinensis L.), Food Chemistry, 121, pp. 264-267.

Vinkovic, V., Kontrec, D., Sunjic, V., Navarini, L., Zanetti, F., Azzolina, O., (2001), Mechanism of chiral recognition in the enantioseparation of 2-aryloxypropionic acids on new brush-type chiral stationary phases, Chirality, 13, pp. 581-587.

Tazerouti, F., Badjah-Hadj-Ahmed, A. Y., Meklati, B. Y., Franco, P., Minguillon, C., (2002), Enantiomeric separation of drugs and herbicides on a $\beta$-cyclodextrin-bonded stationary phase, Chirality, 14, pp. 59-66.

Schneiderheinze, J. M., Armstrong, D. W., Berthod, A., (1999), Plant and soil enantioselective biodegradation of racemic phenoxyalkanoic herbicides, Chirality, 11, pp. 330-337.

Kafkova, B., Bosakova, Z., Tesarova, E., Coufal, P., (2005), Chiral separation of betaadrenergic antagonists, profen non-steroidal anti-inflammatory drugs and chlorophenoxypropionic acid herbicides using teicoplanin as the chiral selector in capillary liquid chromatography, Journal of Chromatography A, 1088, pp. 82-93.

Lao, W. J., Gan, J., (2006a), High-performance liquid chromatographic separation of imidazolinone herbicide enantiomers and their methyl derivatives on polysaccharide-coated chiral stationary phases, Journal of Chromatography A, 1117, pp. 184-193.

Lao, W., Gan, J., (2006b), Responses of enantioselective characteristics of imidazolinone herbicides and Chiralcel OJ column to temperature variations, Journal of Chromatography A, 1131, pp. 74-84.

Lin, K. D., Xu, C., Zhou, S. S., Liu, W. P., Gan, J., (2007), Enantiomeric separation of imidazolinone herbicides using chiral high-performance liquid chromatography, Chirality, 19, pp. 171-178.

Zhou, Q. Y., Xu, C., Zhang, Y. S., Liu, W. P., (2009), Enantioselectivity in the Phytotoxicity of Herbicide Imazethapyr, Journal of Agricultural and Food Chemistry, 57, pp. 1624-1631.

Zhou, Q. Y., Zhang, N., Zhang, C., Huang, L. D., Niu, Y. F., Zhang, Y. S., Liu, W. P., (2010), Molecular Mechanism of Enantioselective Inhibition of Acetolactate Synthase by 
Imazethapyr Enantiomers, Journal of Agricultural and Food Chemistry, 58, pp. 42024206.

Gao, R. Y., Wang, H. F., Chen, Z. Y., Yang, H. Z., Wang, Q. S., (2000), Enantiomer separation and preparation of five organophosphorus compounds and their biological activities, Chromatographia, 51, pp. 322-324.

Li, L., Zhou, S. S., Zhao, M. R., Zhang, A. P., Peng, H., Tan, X. S., Lin, C. M., He, H. W., (2008), Separation and aquatic toxicity of enantiomers of 1-(substituted phenoxyacetoxy)alkylphosphonate herbicides, Chirality, 20, pp. 130-138.

Hou, S., Wang, M., Zhou, Z., Qiao, Z., Guo, H., Shi, X., (2002), Preparation of cellulose-based chiral stationary phase and enantioseparation of ethoxyfen-ethyl by high performance liquid chromatography, Se Pu, 20, pp. 537-539.

Diao, J. L., Lv, C. G., Wang, X. Q., Dang, Z. H., Zhu, W. T., Zhou, Z. Q., (2009), Influence of Soil Properties on the Enantioselective Dissipation of the Herbicide Lactofen in Soils, Journal of Agricultural and Food Chemistry, 57, pp. 5865-5871.

Zipper, C., Suter, M. J. F., Haderlein, S. B., Gruhl, M., Kohler, H. P. E., (1998), Changes in the enantiomeric ratio of (R)- to (S)-mecoprop indicate in situ biodegradation of this chiral herbicide in a polluted aquifer, Environmental Science \& Technology, 32, pp. 2070-2076.

Wen, Y. Z., Cai, X. Y., Ma, Y., Liu, W. P., (2004), Enantioseparation and determination of dichlorprop in water by derivatization-chiral gas chromatography, Chinese Journal of Analytical Chemistry, 32, pp. 1492-1494.

Ma, Y., Liu, W. P., Wen, Y. Z., (2006), Enantioselective degradation of rac-metolachlor and Smetolachlor in soil, Pedosphere, 16, pp. 489-494.

Ma, Y., Xu, C., Wen, Y. Z., Liu, W. P., (2009), Enantioselective Separation and Degradation of the Herbicide Dichlorprop Methyl in Sediment, Chirality, 21, pp. 480-483.

Cole, J., Dolak, L. A., Lefler, J. L., (2007), The chiral resolution of an herbicidal product by SFC, Chimica Oggi-Chemistry Today, 25, pp. 32-36.

Li, L., Zhou, S. S., Jin, L. X., Zhang, C., Liu, W. P., (2010), Enantiomeric separation of organophosphorus pesticides by high-performance liquid chromatography, gas chromatography and capillary electrophoresis and their applications to environmental fate and toxicity assays, Journal of Chromatography B-Analytical Technologies in the Biomedical and Life Sciences, 878, pp. 1264-1276.

Hsieh, Y. Z., Huang, H. Y., (1996), Analysis of chlorophenoxy acid herbicides by cyclodextrin-modified capillary electrophoresis, Journal of Chromatography A, 745, pp. 217-223.

Mechref, Y., El., R. Z., (1996a), Capillary electrophoresis of herbicides. 1. Precolumn derivatization of chiral and achiral phenoxy acid herbicides with a fluorescent tag for electrophoretic separation in the presence of cyclodextrins and micellar phases, Analytical Chemistry, 68, pp. 1771-1777.

Mechref, Y., ElRassi, Z., (1997a), Capillary electrophoresis of herbicides .4. Evaluation of octylmaltopyranoside chiral surfactant in the enantiomeric separation of fluorescently labeled phenoxy acid herbicides and their laser-induced fluorescence detection, Electrophoresis, 18, pp. 220-226.

Mechref, Y., ElRassi, Z., (1996b), Capillary electrophoresis of herbicides .3. Evaluation of octylmaltopyranoside chiral surfactant in the enantiomeric separation of phenoxy acid herbicides, Chirality, 8, pp. 518-524. 
Mechref, Y., ElRassi, Z., (1997b), Capillary electrophoresis of herbicides .2. Evaluation of alkylglucoside chiral surfactants in the enantiomeric separation of phenoxy acid herbicides, Journal of Chromatography A, 757, pp. 263-273.

Desiderio, C., Polcaro, C. M., Padiglioni, P., Fanali, S., (1997a), Enantiomeric separation of acidic herbicides by capillary electrophoresis using vancomycin as chiral selector, Journal of Chromatography A, 781, pp. 503-513.

Ingelse, B. A., Reijenga, J. C., Flieger, M., Everaerts, F. M., (1997), Capillary electrophoretic separation of herbicidal enantiomers applying ergot alkaloids, Journal of Chromatography A, 791, pp. 339-342.

Pirkle, W. H., Lee, W., Welch, C. J., (1997), Chromatographic separation of the enantiomers of 2-aryloxypropionic acids, esters and amides, Enantiomer, 2, pp. 423-431.

Haynes, J. L., Shamsi, S. A., O'Keefe, F., Darcey, R., Warner, I. M., (1998), Cationic betacyclodextrin derivative for chiral separations, Journal of Chromatography A, 803, pp. 261-271.

Jarman, J. L., Jones, W. J., Howell, L. A., Garrison, A. W., (2005), Application of capillary electrophoresis to study the enantioselective transformation of five chiral pesticides in aerobic soil slurries, Journal of Agricultural and Food Chemistry, 53, pp. 6175-6182.

Yi, F., Guo, B. Y., Peng, Z. L., Li, H. F., Marriott, P., Lin, J. M., (2007), Study of the enantioseparation of imazaquin and enantioselective degradation in field soils by CZE, Electrophoresis, 28, pp. 2710-2716.

Han, L., Guo, B. Y., Feng, J. H., Lu, X. M., Lin, J. M., (2008), Study on the Enantioselective Degradation of Imazethapyr in Soil by CE, Chromatographia, 68, pp. 1071-1073.

Pico, Y., Rodriguez, R., Manes, J., (2003), Capillary electrophoresis for the determination of pesticide residues, Trac-Trends in Analytical Chemistry, 22, pp. 133-151.

Nielen, M. W. F., (1993), (Enantio-)separation of phenoxy acid herbicides using capillary zone electrophoresis, Journal of Chromatography, 637, pp. 81-90.

Otsuka, K., Smith, C. J., Grainger, J., Barr, J. R., Patterson, D. G., Tanaka, N., Terabe, S., (1998), Stereoselective separation and detection of phenoxy acid herbicide enantiomers by cyclodextrin-modified capillary zone electrophoresis electrospray ionization mass spectrometry, Journal of Chromatography A, 817, pp. 75-81.

Zerbinati, O., Trotta, F., Giovannoli, C., (2000), Optimization of the cyclodextrin-assisted capillary electrophoresis separation of the enantiomers of phenoxyacid herbicides, Journal of Chromatography A, 875, pp. 423-430.

Garrison, A. W., Schmitt, P., Kettrup, A., (1994), Separation of phenoxy acid herbicides and their enantiomers by high-performance capillary electrophoresis, Journal of Chromatography A, 688, pp. 317-327.

Desiderio, C., Polcaro, C. M., Fanali, S., (1997b), Stereoselective analysis of herbicides by capillary electrophoresis using sulfobutyl ether beta-cyclodextrin as chiral selector, Electrophoresis, 18, pp. 227-234.

Penmetsa, K. V., Leidy, R. B., Shea, D., (1997), Enantiomeric and isomeric separation of herbicides using cyclodextrin-modified capillary zone electrophoresis, Journal of Chromatography A, 790, pp. 225-234.

Zerbinati, O., Trotta, F., Giovannoli, C., Baggiani, C., Giraudi, G., Vanni, A., (1998), New derivatives of cyclodextrins as chiral selectors for the capillary electrophoretic separation of dichlorprop enantiomers, Journal of Chromatography A, 810, pp. 193200. 
Aga, D. S., Heberle, S., Rentsch, D., Hany, R., Muller, S. R., (1999), Sulfonic and oxanilic acid metabolites of acetanilide herbicides: Separation of diastereomers and enantiomers by capillary zone electrophoresis and identification by H-1 NMR spectroscopy, Environmental Science \& Technology, 33, pp. 3462-3468.

Malik, A. K., Aulakh, J. S., Fekete, A., Schmitt-Kopplin, P., (2009), Separation of the Phenoxy Acid Herbicides and Their Enantiomers by Capillary Zone Electrophoresis in Presence of Highly Sulphated Cyclodextrins, Journal of the Chinese Chemical Society, 56, pp. 1163-1167.

Garrison, A. W., Schmitt, P., Martens, D., Kettrup, A., (1996), Enantiomeric selectivity in the environmental degradation of dichlorprop as determined by high performance capillary electrophoresis, Environmental Science \& Technology, 30, pp. 2449-2455.

Andre, C., Berthelot, A., Thomassin, M., Guillaume, Y. C., (2006), Enantioselective aptameric molecular recognition material: Design of a novel chiral stationary phase for enantioseparation of a series of chiral herbicides by capillary electrochromatography, Electrophoresis, 27, pp. 3254-3262.

Messina, A., Sinibaldi, M., (2007), Enantioseparations on chiral monolithic columns: A study of the stereoselective degradation of (R/S)-dichlorprop 2-(2,4dichlorophenoxy)propionic acid in soil, Electrophoresis, 28, pp. 2613-2618.

Buchinger, S., Follrich, B., Lammerhofer, M., Lubda, D., Lindner, W., (2009), Chirally functionalized anion-exchange type silica monolith for enantiomer separation of 2aryloxypropionic acid herbicides by non-aqueous capillary electrochromatography, Electrophoresis, 30, pp. 3804-3813.

Mechref, Y., ElRassi, Z., (1996c), Micellar electrokinetic capillary chromatography with insitu charged micelles VI. Evaluation of novel chiral micelles consisting of steroidal glycoside surfactant borate complexes, Journal of Chromatography A, 724, pp. 285296.

Schmitt, P., Garrison, A. W., Freitag, D., Kettrup, A., (1997), Application of cyclodextrinmodified micellar electrokinetic chromatography to the separations of selected neutral pesticides and their enantiomers, Journal of Chromatography A, 792, pp. 419429.

Martin-Biosca, Y., Garcia-Ruiz, C., Marina, M. L., (2001), Enantiomeric separation of chiral phenoxy acid herbicides by electrokinetic chromatography. Application to the determination of analyte-selector apparent binding constants for enantiomers, Electrophoresis, 22, pp. 3216-3225.

Gavioli, E., Maier, N. M., Minguillon, C., Lindner, W., (2004), Preparative enantiomer separation of dichlorprop with a cinchona-derived chiral selector employing centrifugal partition chromatography and high-performance liquid chromatography: A comparative study, Analytical Chemistry, 76, pp. 5837-5848.

Liu, H. J., Xiong, M. Y., (2009), Comparative toxicity of racemic metolachlor and Smetolachlor to Chlorella pyrenoidosa, Aquatic Toxicology, 93, pp. 100-106.

Kurt-Karakus, P. B., Bidleman, T. F., Muir, D. C. G., Struger, J., Sverko, E., Cagampan, S. J., Small, J. M., Jantunen, L. M., (2010), Comparison of concentrations and stereoisomer ratios of mecoprop, dichlorprop and metolachlor in Ontario streams, 2006-2007 vs. 2003-2004, Environmental Pollution, 158, pp. 1842-1849. 
Chan, J. H. H., Walker, F., Tseng, C. K., Baker, D. R., Arneklev, D. R., (1975), Synthesis and herbicidal activity of N,N-diethyl-2-(1-naphthyloxy)propionamide and its optical isomers, Journal of Agricultural and Food Chemistry, 23, pp. 1008-1010.

Couderchet, M., Bocion, P. F., Chollet, R., Seckinger, K., Boger, P., (1997), Biological activity of two stereoisomers of the N-thienyl chloroacetamide herbicide dimethenamid, Pesticide Science, 50, pp. 221-227.

Shimabukuro, R. H., Hoffer, B. L., (1995), Enantiomers of diclofop-methyl and their role in herbicide mechanism of action, Pesticide Biochemistry and Physiology, 51, pp. 68-82.

Ye, J., Zhang, Q. O., Zhang, A. P., Wen, Y. Z., Liu, W. P., (2009), Enantioselective Effects of Chiral Herbicide Diclofop Acid on Rice Xiushui 63 Seedlings, Bulletin of Environmental Contamination and Toxicology, 83, pp. 85-91.

Maneechote, C., Preston, C., Powles, S. B., (1997), A diclofop-methyl-resistant Avena sterilis biotype with a herbicide-resistant acetyl-coenzyme A carboxylase and enhanced metabolism of diclofop-methyl, Pesticide Science, 49, pp. 105-114.

Cai, X. Y., Liu, W. P., Sheng, G. Y., (2008), Enantioselective degradation and ecotoxicity of the chiral herbicide diclofop in three freshwater alga cultures, Journal of Agricultural and Food Chemistry, 56, pp. 2139-2146.

Diao, J. L., Xu, P., Wang, P., Lu, Y. L., Lu, D. H., Zhou, Z. Q., (2010a), Environmental Behavior of the Chiral Aryloxyphenoxypropionate Herbicide Diclofop-Methyl and Diclofop: Enantiomerization and Enantioselective Degradation in Soil, Environmental Science \& Technology, 44, pp. 2042-2047.

Buser, H. R., Muller, M. D., (1997a), Enantioselective analyses of persistent and modern pesticides. A step toward sustainable agriculture, Chimia, 51, pp. 694-700.

Buser, H. R., Muller, M. D., (1997b), Conversion reactions of various phenoxyalkanoic acid herbicides in soil .2. Elucidation of the enantiomerization process of chiral phenoxy acids from incubation in a D2O/soil system, Environmental Science \& Technology, 31, pp. 1960-1967.

Muller, M. D., Buser, H. R., (1997), Conversion reactions of various phenoxyalkanoic acid herbicides in soil .1. Enantiomerization and enantioselective degradation of the chiral 2-phenoxypropionic acid herbicides, Environmental Science E Technology, 31, pp. 1953-1959.

Harrison, I., Williams, G. M., Carlick, C. A., (2003), Enantio selective biodegradation of mecoprop in aerobic and anaerobic microcosms, Chemosphere, 53, pp. 539-549.

Williams, G. M., Harrison, I., Carlick, C. A., Crowley, O., (2003), Changes in enantiomeric fraction as evidence of natural attenuation of mecoprop in a limestone aquifer, Journal of Contaminant Hydrology, 64, pp. 253-267.

Wen, Y. Z., Yuan, Y. L., Shen, C. S., Liu, H. J., Liu, W. P., (2009), Spectroscopic Investigations of the Chiral Interactions Between Lipase and the Herbicide Dichlorprop, Chirality, 21, pp. 396-401.

Wen, Y. Z., Yuan, Y. L., Chen, H., Xu, D. M., Lin, K. D., Liu, W. P., (2010), Effect of Chitosan on the Enantioselective Bioavailability of the Herbicide Dichlorprop to Chlorella pyrenoidosa, Environmental Science \& Technology, 44, pp. 4981-4987.

Ramezani, M. K., Oliver, D. P., Kookana, R. S., Lao, W., Gill, G., Preston, C., (2010), Faster degradation of herbicidally-active enantiomer of imidazolinones in soils, Chemosphere, 79, pp. 1040-1045. 
Qian, H. F., Hu, H. J., Mao, Y. Y., Ma, J., Zhang, A. P., Liu, W. P., Fu, Z. W., (2009), Enantioselective phytotoxicity of the herbicide imazethapyr in rice, Chemosphere, 76, pp. 885-892.

Diao, J. L., Xu, P., Wang, P., Lu, D. H., Lu, Y. L., Zhou, Z. Q., (2010b), Enantioselective Degradation in Sediment and Aquatic Toxicity to Daphnia magna of the Herbicide Lactofen Enantiomers, Journal of Agricultural and Food Chemistry, 58, pp. 2439-2445.

Omokawa, H., Konnai, M., (1992), Inhibition of Echinochloa crus-galli var. frumentacea seedling root elongation by chiral 1, 3, 5-triazines in the dark, Pesticide Science, 35, pp. 83-86.

Omokawa, H., Ryoo, J. H., (2001), Enantioselective response of rice and barnyard millet on root growth inhibition by optically active alpha-methylbenzyl phenylureas, Pesticide Biochemistry and Physiology, 70, pp. 1-6.

Omokawa, H., Murata, H., Kobayashi, S., (2004), Chiral response of Oryzeae and Paniceae plants in alpha-methylbenzyl-3-p-tolyl urea agar medium, Pest Management Science, 60, pp. 59-64. 


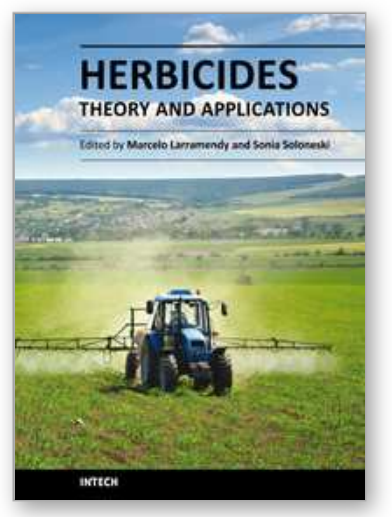

\author{
Herbicides, Theory and Applications \\ Edited by Prof. Marcelo Larramendy
}

ISBN 978-953-307-975-2

Hard cover, 610 pages

Publisher InTech

Published online 08, January, 2011

Published in print edition January, 2011

The content selected in Herbicides, Theory and Applications is intended to provide researchers, producers and consumers of herbicides an overview of the latest scientific achievements. Although we are dealing with many diverse and different topics, we have tried to compile this "raw material" into three major sections in search of clarity and order - Weed Control and Crop Management, Analytical Techniques of Herbicide Detection and Herbicide Toxicity and Further Applications. The editors hope that this book will continue to meet the expectations and needs of all interested in the methodology of use of herbicides, weed control as well as problems related to its use, abuse and misuse.

\title{
How to reference
}

In order to correctly reference this scholarly work, feel free to copy and paste the following:

Lixia Jin, Weiliang Gao, Ling Li, Jing Ye, Chunmian Lin and Weiping Liu (2011). Enantioseparation and Enantioselective Analysis of Chiral Herbicides, Herbicides, Theory and Applications, Prof. Marcelo Larramendy (Ed.), ISBN: 978-953-307-975-2, InTech, Available from: http://www.intechopen.com/books/herbicides-theoryand-applications/enantioseparation-and-enantioselective-analysis-of-chiral-herbicides

\section{INTECH}

open science | open minds

\section{InTech Europe}

University Campus STeP Ri

Slavka Krautzeka 83/A

51000 Rijeka, Croatia

Phone: +385 (51) 770447

Fax: +385 (51) 686166

www.intechopen.com

\section{InTech China}

Unit 405, Office Block, Hotel Equatorial Shanghai

No.65, Yan An Road (West), Shanghai, 200040, China

中国上海市延安西路65号上海国际贵都大饭店办公楼405单元

Phone: +86-21-62489820

Fax: $+86-21-62489821$ 
(C) 2011 The Author(s). Licensee IntechOpen. This chapter is distributed under the terms of the Creative Commons Attribution-NonCommercialShareAlike-3.0 License, which permits use, distribution and reproduction for non-commercial purposes, provided the original is properly cited and derivative works building on this content are distributed under the same license. 